\title{
Fyra berättelser om arbete: Om arbets- attityder och mening och varför man ska arbeta (Del 2)
}

\section{Av Roland Hallgren}

Dessa är de två sista delberättelserna i Roland Hallgrens studie över arbetets etik. De två första publicerades i förra numret av HumaNetten; det rörde sig dels om en introducerande betraktelse, dels en studie av arbetets etik inom våra världsreligioner. I denna avslutande del visar Hallgren dels hur frågor om arbetsetik i kommer fram i svenska skolläromedel, dels vilka attityder unga människor har till arbete utifrån en aktuell enkätundersökning.

\section{En berättelse om läromedelsinnehåll}

\section{Äldre läromedel}

\begin{abstract}
"Varen flitige: ty flit är framgångens moder". (Esaias Tegnér 1782-1846)
"Honom fattades ingenting annat än det oumbärligaste i tillvaron: den glädje som kommer ur arbetet”. (Vilhelm Moberg 1898-1973 ur Sänkt sedebetyg 1935)
\end{abstract}

I denna läromedelsstudie är äldre läromedel sådana som är utgivna tidigare än 1980. Här är min avsikt att undersöka vad läromedel i främst religionskunskap säger om arbete, arbetets mening och värde. Även vid undersökning av modernare skolböcker och annan undervisningslitteratur från 1980 och framåt kommer tonvikten att ligga på läromedel i ämnet religionskunskap.

En liten skrift som av en händelse kom i min hand för ett par år sedan var den första utgivna finländska barnboken tryckt i Åbo 1798, Läseöfning för mina barn av Jacob Tengström. Där finns under avsnittet "Några tänkespråk för barn", utsagor som hyllar arbetet och arbetsvilligheten. "Var flitig i dina sysslor, ty den lata blir av alla föraktad" och "Använd tiden väl i din barndom; därav beror hela din framtida välfärd." Vidare sägs det; "Ledsna ej vid det arbete du företar dig, om det ock ej i början efter önskan vill lyckas dig; håller du flitigt på därmed, så skall det snart gå bättre.” Texten fortsätter i didaktisk anda. "Har du ledsamt, fă för dig något nyttigt att göra. Den flitiga vet aldrig av någon ledsnad." Det påpekas också att "Allt har sin tid. Arbeta har sin tid; leka och roa sig har sin tid." ${ }^{1}$ Det berättas förebildligt om Den beskedlige lärgossen som fått arbete hos en snickare "som genom flit och skicklighet i sin hantering, hade sin goda utkomst." Denne föredömlige snickare är ett föredöme för det läraktiga barnet. ${ }^{2}$ I "Daglig Skole-

1 Jakob Tengström 1798: 58f (Jag har normaliserat äldre citats stavning)

2 Jakob Tengström 1798: 39 
bön" heter det "Giv mig nåd att flitig vara och att tiden nyttja rätt! 3 En daglig bön om att få Guds nåd att vara arbetsam och att använda tiden på ett genomtänkt sätt. En dikt till ”Det stadiga barnet” får avsluta citaten från denna nordiska klassiker. Dikten visar på tidens bestämda behov och uppfattning om nödvändigheten att fostra barnen till flit och nyttighet. Leken är förbi, du blir klokare med åren och fyller tiden med arbete;

"Länge har jag barnslig varit,

Tiden gått i lek förbi;

$\mathrm{Nu}$, då barnaåren farit,

Är det tid att stadig bli,

Att i vett och visdom växa,

Vänjas vid ett nyttigt liv.

Nu skall sysslan och min läxa

Bli mitt bästa tidsfördriv.” 4

Ungefär hundra år senare utkommer en annan

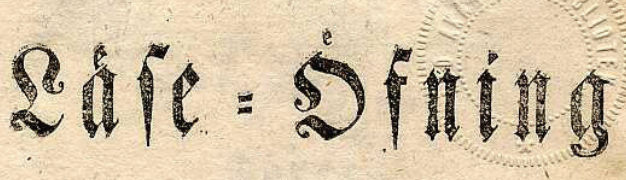

fort
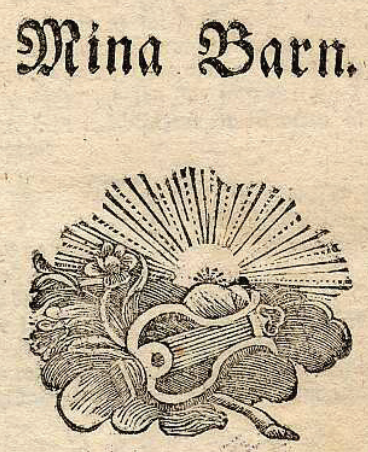

27) Uิplag $\phi_{3}$

शำ, 179\%

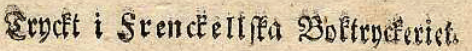
banbrytande bok; Första läsåret. ABC - och Läsebok av B.C. Rodhe som utkom i en mängd upplagor. Den jag använt mig av utkom 1891. En stående rubrik i boken är "Ordspråk”. "Tjäna dig själv så har du en trogen dräng." "Får barnet icke lära sig att arbeta, så lär det sig ofta att stjäla.” Barnen ska inte uppfostras till att vara lata och slarviga utan flit och nytta ska råda. Ska du få något så måste du arbeta för det. ”Flitig bör man alltid vara” ${ }^{6}$ Du ska arbeta dig varm.

"Lättjan föder sorg och nöd och ger aldrig dagligt bröd, men se, flit gör kinden röd och ger bröd i överflöd." 7

Såsom fågeln ska människan stå upp tidigt och stämma upp en sång; ”sedan skynda vi att börja arbetet med fröjd." ${ }_{8}$ Tiden är kort. "Blott för den som flitig är bliver efter slutad möda vilan ljuv och kär.” "Ungdoms möda är ålderdoms ro.” ${ }^{9}$ Inte bara människor sträva och arbeta - det gör även biet och andra djur - allt till Guds lov. Tiden skall för att få värde fyllas med arbete. Det gäller både bi och gossar;

3 Jakob Tengström 1798:89

4 Jacob Tengström 1798: 68

5 B.C Rodhe 1891: 61

6 B.C Rodhe 1891:52

7 B.C Rodhe 1891: 76f

8 B.C Rodhe 1891: 78

9 B.C Rodhe 1891: 82 
"De säga alla, att de icke få vara lata. Då får väl icke heller små gossar vara det. Så skyndade han sig till skolan och blev från den dagen en av de flitigaste i klassen." 10

I Småskolans Kristendomsbok från $1950^{11}$ skriver utgivarna i förordet att de har strävat "efter att åstadkomma en bok, som kan vara en hjälp för läraren i fråga om det rent uppfostrande momentet i undervisningen.” De vill göra barnen ” förtrogna med vissa livsvärden och hos dem skapa den stämning och den inställning, som är viktiga för en fruktbringande kristendomsundervisning under de senare skolåren.” Huvuduppgiften verkar vara att erbjuda barnen ett grundläggande moraliskt förhållningssätt. Berör då denna relativt tunna och illustrerade bok på drygt femtio sidor arbete i någon form? Ja, där sägs att livet är en tjänst för Gud. ’Låt också mig få växa till tjänst i Ditt rike.” ${ }_{22}$ ”Jag vill vara rädd om allt som lever och växer." ${ }_{13}$ Efter några inledande bibelberättelser så börjar andra skolåret med ett uppslag som heter "Arbete och vila”. Där kan vi läsa att; "Dagen ger arbete, och natten ger vila." Om morgonen skyndar man "att börja arbetet med fröjd." "Blott för den som flitig är, bliver efter slutad möda vilan ljuv och kär." och när arbetsveckan är slut så "ringer kyrkans klockor in helgen.”" ${ }^{14}$ Livet är en rimlig fördelning mellan arbete och vila och med ett glatt sinne bör arbetet utföras - arbete är här alls inget straff utan en gudagiven ynnest. Ditt arbete är en del i en större plan där du inte ska neka behövande din hjälp och där det tas för givet att "Kamrater hjälps åt i arbetet.” ${ }_{15}$ Du ska fostras in i ett arbetande och framåtskridande folkhem.

Läroboken Människan och livsåskådningarna. Religionskunskap för gymnasiet och fackskolan. kom 1969 på förlag Almqvist \& Wiksell. ${ }^{16}$ Där finns ett avsnitt som tar upp marxismens människouppfattning om att arbetet skapar människan - förtryck och utsugning gör henne moraliskt ond, men när klassamhället avskaffas kan människan bli herre över världen och vara till för andra på ett nytt sätt. ${ }^{17}$ Läroboken behandlar även roller och arbetsfördelning mellan man och kvinna i hemmet/äktenskapet. ${ }^{18}$ Där finns även ett stort avsnitt om ”Arbetet och social rättvisa” (191-206). I detta kapitel tas viktiga punkter upp om synen på arbete: Är det ett straff - vilket värde har det - vad är rättvisa - vad säger religionerna? Det inleds med ett avsnitt om västerländsk syn på arbete (kroppsarbete). Det ger motiveringar för arbete: självförverkligande med hjälp av motiveringen att du är som kuggen i maskinen, (du är en viktig del av helheten) och den sociala motiveringen (arbeta för allas bästa). ${ }^{19}$ Där tas även upp om rättvisa i arbetslivet samt socialt ansvar. ${ }^{20}$ Därefter ges marxismens syn, judisk och islamisk samt buddhistisk och hinduisk. Det

10 B.C Rodhe 1891: 99f

11 Herman Gottfrid Pihl o Anna Maria Roman, citat från Förord III 1950

12 Som ovan Förord III, 1950:4

13 Som ovan Förord III, 1950:9

14 Herman Gottfrid Pihl o Anna Maria Roman 1950:22f

15 Herman Gottfrid Pihl o Anna Maria Roman 1950: 24,26

16 Hans Hof, Jan Hammarstedt, Clarence Nilsson 1969

17 Hans Hof et al 1969:153

18 Hans Hof et al 1969:177

19 Hans Hof et al 1969:191ff

20 Hans Hof et al 1969:195 
sägs även något om konfucianism och kommunism i kinesiskt samhällsliv. ${ }^{21}$ En fördjupningsbok av Hof och Hammarstedt, en antologi med texter gavs ut 1971 och beskrivs nedan.

Religion och tanke är en lärobok som i sin undertitel kallas för en studiehandledning för gymnasiet (Gleerups förlag) och gavs ut 1970..22 Där finns ett avsnitt "Vårt arbete" som börjar med att problematisera arbetet som en plågsam börda i pressande klimat och beskriver den skillnad i historien som finns genom en uppdelning av fria människor som inte arbetar och arbetande trälar. En sådant tudelat motsatsförhållande kan ge förakt för arbete, det vill säga kroppsarbete. I boken berörs även arbetets ändamål som sägs vara försörjning och att ge tillvaron mening. Arbetets värde lönesätts och rätt lön ger sedan arbetaren tillfredställelse. ${ }^{23}$ Kristendomens arbetsidé är enligt författarna "varje persons plikt att ägna sig åt nyttigt arbete.” ${ }^{24}$ Luthers kallelsetanke berörs liksom marxismens syn på arbetet. Det sägs att det är viktigt att ha ett arbete för det är inte "en lyckosam tillvaro att sakna ordnad sysselsättning." ${ }^{25}$

Harry Hermerén var detta år på samma förlag också författare till en lärobok i religionskunskap för grundskolans högstadium. ${ }^{26}$ Arbete ägnas där ett särskilt avsnitt som heter "Vårt arbete”. Avsnittet inleds med frågan "Varför arbetar människan?" Det svar som ges är närmast att människan ska arbeta för att kunna försörja sig. Men även meningsfrågor berörs. Religionernas svar tas upp från ett kristet perspektiv där meningen med arbete kopplas till människovärde och vikten av att ha ett arbete som känns personligt och utvecklande. Det finns ett avsnitt om solidaritet $\mathrm{i}$ arbetslivet och om värdering av olika yrken. Det ger tips på vidareläsning samt återblicksfrågor och övningsuppgifter. ${ }^{27}$ Det är ett utvecklingsbart och genomtänkt avsnitt med ett bra bildmaterial men sannolikt för avancerat för dagsbruk. Genomgående i min framställning så gör jag värderingar och ger egna reflektioner när jag känner att det gagnar läsaren även om det i slutet av kapitlet följer en sammanfattande analys.

Den ovan omnämnda fördjupningsboken Människan och livsåskådningarna har Fördjupningstexter som gavs ut på A\&W och är en fristående antologi. Den är avsedd att användas på gymnasium och fackskola oavsett vilken grundbok i religionskunskap som används ${ }^{28}$ Där finns ett kapitel "Arbetet och social rättvisa". Ett avsnitt där är "Fyra frågor om arbetet”, skrivet av Ludvig Jönsson. ${ }^{29}$ Svaren som ges är relaterade till ett kristet perspektiv. Jönsson utgår från den positiva människosynen och uppfattningen att människan är en gemenskapsvarelse som vill ha en uppgift att fylla. I detta perspektiv har människan ett behov av att behövas och duga någonting till. Hon vill göra en insats,

21 Hans Hof et al 1969: 197-205

22 Harry Hermerén och Einar Lilja 1970

23 Harry Hermerén och Einar Lilja 1970: 77f

24 Harry Hermerén och Einar Lilja 1970:77

25 Harry Hermerén och Einar Lilja 1970: 78

26 Harry Hermerén 1970

27 Harry Hermerén 1970: 263ff, $272 f$

28 Hans Hof och Jan Hammarstedt 1971

29 Hans Hof och Jan Hammarstedt 1971: 318-331 
inte bara för sig själv utan också för andra, men för de flesta är arbetet ett försörjningsmedel för en själv eller ens familj. Det finns ett fåtal privilegierade arbeten där den som arbetar ser de människor som mottar ens prestationer. Bland annat, enligt Jönsson, läraren, läkaren, sköterskan, prästen. Han för här in kallelsemotivet för i dessa yrken finns en nära relation till en medmänniska. I dagens produktionssystem, menar han, är känslan av att finnas till för en medmänniska avlägset. ${ }^{30}$ Jönsson tar också upp yrkesskicklighetens betydelse och ansvarskänslan som "ett självklart kapitel i arbetsetiken". ${ }^{31}$ Enligt honom finns hos unga människor en vilja till ansvar. Han berör även solidariteten som ett av "de finaste dragen i modernt arbetsliv". ${ }^{32}$ Författaren söker ett religiöst motiverat ansvar trots svårigheten att aktualisera Gud i dagens situation (i.e. 1970), men var och en är också ansvarig inför sig själv såsom människa och vi vet hur en människa bör vara - inte fuskande och undanglidande utan noggrann och hederlig. Här kommer han in på stöld i arbetslivet och dess etiska konsekvenser. Ludvig Jönsson framhåller också uppfattningen om alla människors lika värde. Inga yrken ska betraktas som "finare" eller bättre än andra. För att utveckla en personlig växt och mognad behövs dock både uppfostran och undervisning. 'Vad jag kan bli' är inte så viktigt som 'Vem kan jag bli. ${ }^{33}$

På Natur \& Kultur kom 1971 Religionskunskap. Lärobok i kristendomskunskap för grundskolan. Årskurs 9. ${ }^{34}$ Arbete berörs mycket kort i kapitlet "Samhället och plikterna mot medmänniskan." Där sägs arbete höra till "de allmänt erkända förpliktelserna i vårt land. ${ }^{35}$ Detta utvecklas inte i texten förutom att det i slutet av kapitlet finns en fråga att arbeta vidare med - "Vem, anser vi, skall ge alla medborgare möjlighet till utbildning, sjukvård, arbete osv?" ${ }_{6}$

1979 kom på Esselte Studium boken Livsfrågor av Sven-Åke Selander, Nils Beltzén, Benkt-Erik Benktson, Yngve Bogren och Olof Pettersson. I ett religionshistoriskt perspektiv behandlas buddhismen och synen på arbete främst relaterat till förhållanden i Japan. Författarna för fram en positiv buddhistisk syn. Det finns ingen passivitet i fråga om livet här och nu. ${ }^{37}$ Några andra religioners arbetsattityder utöver denna och den kristna nämns inte. I boken finns ett avsnitt som heter "Arbetslivets problem". ${ }^{38}$ En notering som kan göras är att det inte är någon positiv titel på avsnittet - varför ses arbetet och arbetslivet ofta som ett problem? "Arbetslivets möjligheter" vore ett bra alternativ till underrubrik. Författarna menar att "arbetet bör ha en skapande betydelse för att kunna upplevas som meningsfullt.” ${ }_{39}$ Vidare berättas i avsnittet om bibelns både positiva och negativa uppfattning. Jesus syn på rikedomar och Pauli syn på arbete refereras. I NT värderas både arbete och vila högt. Boken tar där också upp arbetet som ett kall, som

30 Hans Hof och Jan Hammarstedt 1971: 318ff

31 Hans Hof och Jan Hammarstedt 1971: 321

32 Hans Hof och Jan Hammarstedt 1971: 322

33 Hans Hof och Jan Hammarstedt 1971: 326

34 Lennart Husén, Gunnar Ståldal, Birgitta Lundblad, Tore Zetterholm 1971

35 Lennart Husén et al 1971: 140

36 Lennart Husén et al 1971: 149

37 Sven-Åke Selander et al 1979: 72, jfr 92

38 Sven-Åke Selander et al 1979: 164ff

39 Sven-Åke Selander et al 1979: 164 
en varje persons gudstjänst. Calvins syn refereras och han ser arbetet som en kristen plikt. Den kristna "Hustavlans” folkliga betydelse samt den socialdemokratiska broderskapsrörelsens jämlikhetskrav berörs. ”Enligt kristen tro har människan till uppgift att använda sina olika resurser i arbetet på att göra denna värld så bra som möjligt.” ${ }^{40}$ I detta sammanhang tas även påvens syn upp. Den sägs vara att individen skapar sin framgång efter den inriktning Skaparen gett. Dag Hammarskjöld kommer genom sina Vägmärken till tals. Det viktigaste är att genom arbetet tjäna Gud. Området avslutas med en ruta (frågeruta) för information och samtal, analys och debatt.

\section{Nyare läromedel}

Som nyare läromedel menas i detta avsnitt läromedel utgivna efter 1980. Det ligger en klar tonvikt på läromedel från 1995 och senare år. Texter om livet och människan är en bok för gymnasiet av Lilian Nilsson, Per Hinton och Sven-Åke Selander och kom 1981 ut på Esselte Studium. Texten till detta avsnitt har sitt ursprung i Kristet Forum 2/1976. Avsnittet innehåller funderingar kring arbetets mening följt av en frågeruta med frågor relaterade till detta. ${ }^{41}$ Där finns även en text ur samma källa om arbetslösheten i Sverige..$^{22}$ Detta mynnar ut i frågor om arbete är en grundläggande mänsklig rättighet och om förhållandet mellan arbete och människovärde. Hur ska arbetet bli meningsfullt? Det första avsnittet är upplagt så att olika röster får redovisa sina svar på frågan om arbetet har en mening och i så fall vilken. Fyra av fem svarande bland dessa röster har en klar kristen bakgrund.

Religionskunskap är en Esseltebok som kom ut i en tredje upplaga 1985 (första uppl.1972). Den är författad av Sten Rodhe och Erland Sundström. Under "Moralfrågor i teori och tillämpning" finner vi att det om arbetsmoral slås fast att rätten till arbete är en enligt FN mänsklig rättighet. Där talas i avsnittet även om arbetsfrågor som centrala och om moraliska samhällsfrågor och det slås fast att arbetslöshet är något ont. Rätt lön i förhållande till utfört arbete omtalas som en rättvisefråga. Där sägs att; "Synen på arbetet hänger nära samman med religion och livsåskådning.” ${ }_{43}$ Denna utsaga kan nog äga sin riktighet men är inget synsätt som fullt ut avspeglas i de läromedel jag studerat. Rodhes och Sundströms lärobokstext tar också på dessa sidor i boken upp något om synen på arbete i olika religionssammanhang. Det som berörs är Paulus, Luther, klosterregler som "Be och arbeta”, samt attityder till arbete från det klassiska Grekland. I sin helhet en rätt intressant text att använda som underlag för diskussion.

En bok som kom 1989 på Esselte Studium var Religion för högstadiet av Bo Nylund och Melker Wesslegård. Där finns inget om etik relaterat till arbetets värde eller om arbetsmoral. ${ }^{44}$ Det syns som om läroböcker för gymnasiet mer än läroböcker för grundskolans senare del tar upp perspektiv på arbete och arbetets värde. En sådan gym-

$40 \quad$ Sven-Åke Selander et al 1979: 165

41 Lilian Nilsson, Per Hinton, Sven-Åke Selander 1981: 136-141

42 Lilian Nilsson et al 1981: 141-144

43 Sten Rodhe och Erland Sundström 1985: 249, se även föreg. sida samt 250

44 Bo Nylund/Melker Wesslegård 1989 
nasiebok är Vad är religion?, författad av Anita Diehl och Lars Andersson och utgiven på Akademiförlaget 1991. Där finns ett avsnitt som kallas " Rätten till arbete och samhällsfunktion". Där finns inget uttryckligen om arbetets mening, arbetsmoral eller om arbetsetik utan texten handlar mer om det är en plikt att arbeta eller ej. Där ställs ett antal frågor som exempelvis; "Arbetar människan för att leva eller lever hon för att arbeta?” _ ”Är arbetet ett kall?” Förädlar människan sig genom sitt arbete eller är arbetet enbart instrumentellt materiellt - uttrycker vi oss genom vårt arbete? ”Arbetar vi för att lämna spår, för att visa att vi faktiskt existerar och existerat?” ${ }^{45}$ Intressanta frågor att diskutera.

Boken Livstro, (Carl Eber Olivestam, Håkan Thorsén och Ann Westermark), är en lärobok i religionskunskap för gymnasieskolan på förlaget Almqvist\&Wiksell. I denna bok från 1992 tas ett intressant grepp. Boken har en fyllig del om arbete och mening, konstaterande; "En stor del av vårt liv arbetar vi människor. Varför gör vi det? Vad finns det för mening med det?” ${ }_{46}$ Avsnittet inleds som en tecknad serie där en kille funderar och ställer frågor till olika yrkesarbetare; Varför jobbar du? Han ställer också frågor som; Vad gör livet värdefullt för dig? Inga av svaren relaterar dock direkt till arbete..77 Frågor ställs i serieform; Vad är syftet med livet? Alla svaren erbjuder möjlighet till nya reflektioner - alla tycker nämligen olika. ${ }^{48}$ Så presenteras fyra vanliga synsätt på frågan om vad som är arbetets mening. ”Arbetet är ett medel för att kunna förverkliga viktiga värden utanför arbetet.” ”I arbetet kan människan tillfredställa grundläggande mänskliga behov.” ”Arbetets mening ligger i dess kollektiva mål.” ”Arbetets mening är att vara medarbetare till Gud.” Efter att dessa utsagor förtydligats i texten så följer uppgifter i tre avdelningar med sammanlagt nio diskussionsfrågor. ${ }^{49}$ Avsnittet är föredömligt kopplat till det följande "livets mening”. Arbetets villkor berörs även i avsnittet Marxism. ${ }^{50}$

Religion 1. Rondo, är en bok för högstadiet förlagd på Almqvist \& Wiksell 1995 och författad av Bo Nylund och Melker Wesslegård. I denna bok finns inget uttryckligt avsnitt om arbete. I ett avsnitt ” Människan skapar” sägs att "Både djur och människor arbetar”. Djuren sägs vara låsta till ett medfött arbetsprogram medan vi människor vill överskrida gränser. Men; ”Vi vill inte vara slavar under ett arbetsprogram, som andra tänkt ut.” ${ }_{51}$ Arbetet skildras, i den mån det kortfattade inslaget kan tolkas, ganska negativt. I en recension från Aftonbladet, en av de få dagstidningar som recenserar skolbokslitteratur, den 11/1 2005 säger Göran Hägg "infantiliserad” om systemet Rondo 1-3 och är i övrigt inte nådig i sin kritik. ${ }^{52}$ En annan lärobok i religionskunskap på Gleerups förlag från samma år (Religionskunskap SO-boken 7-9) har inget om arbete. ${ }^{53}$

\footnotetext{
45 Anita Diehl och Lars Andersson 1991: 227f

46 Carl Eber Olivestam/Håkan Thorsén/Ann Westermark 1992: 156

47 Carl Eber Olivestam et al 1992: 156f

48 Carl Eber Olivestam et al 1992: $158 \mathrm{f}$

49 Carl Eber Olivestam et al 1992: 160ff

50 Carl Eber Olivestam et al 1992: 178

51 Bo Nylund/Melker Wesslegård 1995: 9f

52 http://www.aftonbladet.se/kultur/bokrecensioner/article258214.ab

53 Magnus Hermansson/Nils-Åke Tidman 1995
} 
Läroböcker, arbetspärmar, pedagogpärmar etc. för högstadiet med titeln Religion och liv som jag undersökt, författade av Leif Berg från 1996 fram till 2006 tillsammans med olika medförfattare inom det så kallade Sol-systemet på Natur och Kultur, finns i läroböcker eller i arbetsböcker inget material eller några perspektiv relaterade till arbete, arbetsmoral eller arbetsetik. ${ }^{54}$

Religionskunskap. Möte med livsfrågorna, 7-9. Temaboken, är en högstadiebok i Pulsserien på Natur o Kultur från 1996. De tre författarna är alla kvinnor och avviker från det gängse mönstret att undvika undervisningsmaterial om arbete. Det första temat i boken som är uppbyggd på tolv tema är "Skola och arbete”. Första avsnittet heter ”Arbetets glädje - arbetets plåga" och handlar om arbetet i skolan. Där finns avsnitt om arbetets mening och om meningsfullt och meningslöst arbete liksom om arbetslöshet. Andra kapitlet handlar om att arbeta för Guds skull med exempel från bland annat kristen och muslimsk kontext. Tredje kapitlet ger ett Vi och Dom - perspektiv på olika slags arbete. I boken finns det gott om frågor som eleverna ska fundera över och diskutera. Fjärde kapitlet är om lön för mödan - om lönearbete och skolbetyg. Trots detta relativt stora inledande avsnitt så nämns inget om arbetsmoral eller arbetsetik. Men det är ändå så att i de böcker som jag undersökt finns inget motsvarande denna Pulsupplagas välutvecklade arbetstema. ${ }^{55}$

En bok från samma år med material relaterat till gymnasiets B-kurs är Tema. Tro i tid och rum med Ulf Wagner som redaktör och Gleerups som förlag. Den presenterar tematiskt några ämnen och frågor inom religionskunskapsämnet. Det finns i den dock inget som ansluter till synen på arbete. ${ }^{56}$

De nyss nämnda författarinnorna Boel Westerberg och Wiwi Samuelsson återkommer 1997 på Natur o Kultur med en ny högstadiebok Möte med livsfrågorna. ”Förklaringar och fakta". Där finns hänvisningar till den tidigare nämnda Temaboken från 1996. I ett avsnitt ställs frågan: ”Varför arbetar vi?” - ”Människan är det viktigaste och varje människa har rätt att utvecklas i sitt arbete och leva ett bra liv." ${ }_{57}$

På Gleerups förlag kom 1998 ut en bok för Gymnasiet som heter Relief $A+B$ Religionskunskap av fem delförfattare, alla män. Där finns något om yrkesetik men inget om arbetsmoral eller om attityder till arbete. ${ }^{58}$ Två av författarna, Nils-Åke Tidman och Magnus Hermansson gav året efter ut en lärobok för grundskolans senare stadier, Religionskunskap Kompakt. Även den på Gleerups förlag. I den finns inte något om arbete relaterat till etik eller moral. ${ }^{59}$ Samma gäller Religion. Människor och tro från 2001. En

54 Se litteraturlista Leif Berg/Gudrun Ericson, Leif Berg/Lennart Husén, Leif Berg/Gunilla Rundblom

55 Boel Westerberg/Ulla-Karin Holgersson/Wiwi Samuelsson 1996: 4-18

56 Ulf Wagner (red) 1996

57 Boel Westerberg och Wiwi Samuelsson 1997: 3ff, cit. 216

58 Håkan Arlebrand/Bengt Arvidsson/Hans Axelsson/ Magnus Hermansson/Nils-Åke Tidman 1998: $124 \mathrm{ff}$

59 Nils-Åke Tidman och Magnus Hermansson 1999 
bok för grundskolans senare år av Björn Falkevall et.al på A\&W.60 Inget om arbetets mening eller värde.

Samma år utkom på Interskol även gymnasieboken Religion A\&B 2000 av Birgitta Thulin och Sten Elm. Ett kort stycke på nio rader handlar om Arbete. Där berättas att religionernas syn på arbete är kluven. Där talas även om att det finns en kristen förvaltningsmoral. "Var och en ska efter förmåga göra sitt bästa.” Detta ska ge välstånd åt alla. Där finns inget om arbetets meningsfrågor i ett större sammanhang eller om attityder till arbete. I avsnittet talas även om etiska regler inom religioner och livsåskådningar som föreskriver skatt, allmosor och gåvor. Texten är kort och förhållandevis oklar. Inga samtalsfrågor eller problem är knutna till avsnittet. ${ }^{61}$

Dilemma - om rätt och fel, etik och moral, av Uriel Hedengren kom 2002 på Natur o Kultur. Det är en fakta- och diskussionsbok om etiska problem för högstadiet. Där finns ett avsnitt om mobbning i arbetslivet men inget om attityder till arbete som ett dilemma i sig. ${ }^{62}$ I samma serie utkom 2007 Identitet - vilka är du? av Hammarén/Johansson. Där finns utmärkta möjligheter att ta upp något om arbetets betydelse för identitet men inget sådant försök görs i denna bok. ${ }^{63}$ En annan lärobok, som kom på Gleerups förlag samma år var Punkt SO Religion A Stadiebok, Grundbok 1-3 av Håkan Arlebrand et al. Boken är tom på perspektiv om arbete eller arbetsmoral. ${ }^{64}$ Året innan, 2006 kom en Grundbok Religion ut på Natur o Kultur för årskurs 4-6 av Marianne Abrahamsson utan något om synen på arbete i texten. ${ }^{65}$ På samma förlag kom 2007 Din tro eller min? Religionskunskap för gymnasiet Kurs B av Erica Appelros et al. Där finns ett avsnitt om yrkesetik (s114-122) och om etiska riktlinjer men inget om attityder till arbete eller någon diskussion om arbetsmoral eller om värdet av att arbeta. ${ }^{66}$

Lars-Göran Alms lärobok Religionskunskap för gymnasiet från 1997 på Natur o Kultur, Kurs A kom i en reviderad upplaga först 2002 och sedan 2009 utan något innehåll relaterat till arbete. Ser man däremot på tidigare upplagor från 1997 och 1999 (A o Bkursen om Arbetslivet) är det annorlunda. Boken från 1997 har ett avsnitt som till vinjett har en bild med tre arbetande myror. Texten handlar om arbetslivet. Där sägs att det är viktigt i livet att ha ett arbete, inte bara ekonomiskt utan även socialt och psykiskt. Avsnittet tar upp attityder till kamrater och att var och en ska tillåtas arbeta efter sin förmåga. "Människan får aldrig reduceras till enbart arbetskraft”. Avsnittet talar inte om etik eller moral i någon form - orden nämns inte. ${ }^{67}$ Varför arbetsavsnittet är borta i de senare upplagorna från 2002 och 2009 tål att funderas på. Kanske har det kommit kritik mot de arbetande myrorna som bild för mänsklig aktivitet. Kanske har det blivit allt omöjligare att tala om arbetsetik och arbetsmoral i läroböcker trots att det enligt min mening borde

60 Björn Falkevall, Annika Thor, Ewa Wärmegård 2001

61 Birgitta Thulin och Sten Alm 2001:175

62 Uriel Hedengren 2002

63 Nils Hammarén och Thomas Johansson 2007

64 Håkan Arlebrand/Hans Olofsson/Rolf Uppström 2007

65 Marianne Abrahamsson 2006

66 Erica Appelros/Anne-Christine Hornborg/Helena Röcklinsberg 2007

67 Lars-Göran Alm 1997:141f 
tillhöra samhällets värdegrund. Är det självcensur eller förlagscensur? Arbetsetik och arbetsmoral verkar vara stigmatiserade begrepp i skolsystemets undervisningssammanhang. Jag frågar mig varför? Vilka sätter agendan?

Jag har också läst och undersökt några läromedel i Samhällskunskap och Historia. Här följer nu mina iakttagelser från dessa.

Gleerups reflex, Samhällskunskap för gymnasieskolan, A-B-C kurs av Hans Almgren et al från 1995 tar upp något om två synsätt - det bibliska (straffet att arbeta) och ett positivt (behovet att arbeta). Författarna menar att de båda synsätten fortfarande präglar vår uppfattning om arbetet. Det är en bra början som förenklar och öppnar upp för reflektion och diskussion men som tyvärr glöms bort i den följande texten. Inga frågor eller arbetsuppgifter relaterade till arbetsetik/moral finns med. Inte heller följs inledningens problematisering upp. ${ }^{68}$ Samhällskunskap Kompakt på samma förlag (1996) ställer frågan; "Hur värderas arbete i Sverige? Svaret blir lön, status och andra förmåner. ${ }^{69}$ Synen på arbete, arbetsetik och moral berörs ej.

I Puls, Samhällskunskap för grundskolans senare del av Göran Körner et al på Natur o Kultur från 2002 (s 29) sägs det att; "I den gamla skolan skulle man vara nöjd med sin lott, arbeta hårt och lyda överheten.” Det talas i boken om utanförskap och att "Den arbetslöse känner sig värdelös och utanför gemenskapen”. Där ställs i ingressen till kapitlet frågan; "Väljer du själv din framtid?” och på frågan ”Varför arbetar vi?” svarar författarna; för pengar, gemenskap, nya kunskaper, för individen och kollektivet, överleva, älska sitt arbete..$^{70}$ Författarna skulle kunna utvecklat frågan varför vi ska arbeta på ett tydligare sätt när den nu ändå ställs.

På samma förlag utkom 2003 Samhälle i dag 7-9, Elevbok av Karin Wergel et al. I ett avsnitt som heter "Arbete - mening och innehåll” tas frågan upp om varför vi arbetar - svar ges att det är för lön, arbetet utvecklar människan, för makt, inflytande och gemenskap. Det ställs en fråga som eleverna förväntas arbeta med - "Arbete kan betyda olika saker för olika människor. Ge några exempel?” ${ }^{{ }_{1} 1}$ Boken innehåller inget djupare material om behov av arbete eller om moraliska och etiska problemställningar.

Historia Kompakt, ett läromedel för grundskolans senare årskurser är en bok utgiven 1999 på Gleerups förlag av Hans Almgren et al. I boken finns inget om arbetets värde eller arbetsetik/moral, heller inget om synen på arbete i olika tider och kulturer. ${ }^{72}$

Levande Historia 8-9, Sol 3000 från 2003 av Kaj och Lars Hildingson på Natur o Kultur har ett avsnitt som heter "Leva i Sverige”. Om 1800-talet sägs det att "Så länge man var vaken borde man arbeta” - det sägs även att barn under denna tid måste börja hjälpa till i fyra-femårsåldern. I denna text för åttonde årskursen finns inget om synen på arbete i ett kulturellt/historiskt perspektiv. I texten för nian talas om fackföreningar som arbetar för högre löner och kortare arbetsdag. ${ }^{73}$

68 Hans Almgren, Stefan Höjelid, Erik Nilsson 1995:204f

69 Sture Långström, Erik Nilsson, Göran Swanelid 1996:45

70 Göran Körner, Lars Lagheim, Anna Lagheim 2002:133-135

71 Karin Wergel, Kaj Hildingson, Lars Hildingson 2003:312f

72 Hans Almgren, Stefan Wikén, Birgitta Almgren 1999

73 Kaj Hildingson/Lars Hildingson 2003:388, 446 
Alla tiders historia. Maxi, är ett läromedel för gymnasiet från Gleerups förlag. Boken är skriven av Hans Almgren et al och är från 2003. Inte heller i denna lärobok finns något om synen på arbete i ett historiskt/kulturellt perspektiv. Det finns ett avsnitt om "Kvinnor och män i industrisamhället", men som inte berör något av det ovan nämnda. Det är som i flera andra läromedel svårt att hitta uppslagsord som är kopplade till arbete. Det kan exempelvis nämnas att slavarbete inte finns med som indexerat ord i Alla tiders historia. $^{74}$

Almqvist o Wiksell gav 2006 ut Epos Historia, ett läromedel för gymnasieskolans A och B kurs författat av Robert Sandberg et al. Boken tar upp om arbetstid, arbetslöshet och ekonomi men har inget material om synen på arbete eller om arbete över tid i ett historiskt perspektiv. ${ }^{75}$

Enligt äldre tiders uppfordrande pliktmoral är livsuppgiften att arbeta i sitt anletes svett ty tiden är kort och mycket finns att göra. Denna lutherska syn är vägledande i äldre läromedel fram till mitten av nittonhundratalet, i enstaka fall även senare. Det är en utveckling från att arbeta för Gud och Guds rikes skull, över att arbeta för kollektivets skull och fram till att man arbetar mest för sin egen skull. Arbetet ses ofta som ett problem, mer sällan som en möjlighet. Att synen på arbete och livsåskådning hör samman avspeglas inte i någon högre grad i den läromedelslitteratur i religionskunskap som jag studerat. Det finns, misstänker jag, en rädsla för att koppla arbete till religiös uppfattning. Det finns några läromedel som skiljer sig och där försök görs att integrera synen på arbete i religionskunskapsämnet. Där kan nämnas Hof/Hammarstedt 1971, Rodhe/Sundström 1985, Olivestam et al från 1992, Westerberg et al från 1996 liksom Alm i en upplaga från 1997. Däremot används orden arbetsetik och arbetsmoral ytterst sällan i de texter som handlar om arbete. Hof/Hammarstedt nämner arbetsetik vid ett tillfälle och yrkesetik talas det om i en lärobok vid ett annat tillfälle. Arbete relaterat till resonemang som berör etik och moral är inte vanligt förekommande i de läromedel jag undersökt och arbetsetik och arbetsmoral verkar vara begrepp som bär på ett stigma som gör dem närmast förbjudna i samhällsorienterande lärobokstexter. Är det självcensur? Är begreppen politiskt omöjliga? En annan iakttagelse jag gjort är att de böcker som skriver om arbete i undantagsfall är inriktade på grundskolans högstadium. Flertalet av böckerna som tar upp arbete är gymnasieinriktade.

Även läroböcker i samhällskunskap och historia har liknande brister. Antingen undviker de problematiken om arbete och arbetets mening eller så förs ett i tiden begränsat och ytligt resonemang.

Avslutningsvis följer några tankar som väckts av min läromedelsstudie. Det borde gå att åtgärda bristerna genom att synen på arbete och arbetets mening delades upp på ämnena religionskunskap, historia och samhällskunskap. Uppdelningen kunde ske på så sätt att de tre ämnena fick olika ansvarsområden som med genomtänkt progression kan tänkas behandla arbete exempelvis i nian och i den avslutande gymnasieklassen.

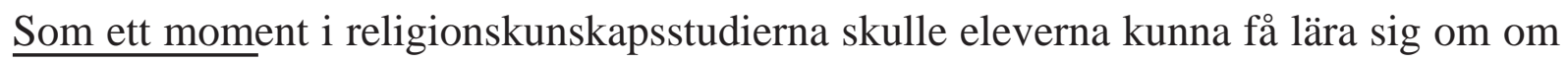

74 Hans Almgren, Arne Löwgren, Börje Bergström 2003:317

75 Robert Sandberg, Per-Arne Karlsson, Karl Modin, Ann-Sofie Ohlander 2006 
synen på arbete inom olika religioners skrifter och praxis samt bli förtrogna med begreppen arbetsetik och arbetsmoral och deras betydelse och innehåll. Inom historieämnet kunde eleverna få studera synen på arbete över tid och arbetets betydelse i olika kulturer och politiska system. Arbete; Förändring och kontinuitet - skulle kunna utgöra ett idéhistoriskt tema. I ämnet samhällskunskap skulle arbetets samband med politiska, juridiskt rättsliga och fackliga frågor undersökas. Synen på arbete i dagspolitiken och i nyhetsrapportering är en given fråga liksom elevernas personliga attityder till arbete och arbetets mening. Sammantaget skulle sådana studier utifrån olika ämnesperspektiv bidra till ökad förståelse för arbete som en mänsklig kulturyttring. Dessa studier bör vara återkommande genom skolsystemet. Jag slutar med följande reflektion. Skolan kan måhända orientera eleverna teoretiskt om arbetsetik och arbetsmoral men att leva och arbeta etiskt lärs nog bäst ut genom kontakt med medmänniskor i konkreta arbetssituationer. Jag tänker på behovet av praktik och yrkesförlagd verksamhet inom skolsystemet liksom om nödvändigheten och skyldigheten för samhället att skapa arbeten åt de unga när de slutar skolan. Det gäller att ge arbetsmöjligheter för både de som går korta yrkesinriktade program och för de som går längre akademiska utbildningar. En utmaning för de politiker som i nuläget är passiva.

\section{En berättelse om ungdomars syn på arbete}

"Ingenting är så strävsamt som att leva utan att göra någonting."

(Fritiof Nilsson Piraten, Medaljerna - Tom bryter en bana, 1973)

Våren 2012 var jag ute på ett antal gymnasieskolor i Kalmarområdet och genomförde en enklare enkätundersökning. Följande åtta frågor användes;

\section{Frågor om arbete}

Kön: Ålder: Program o åk: Födelseland:

1. Är det viktigt för Dig att ha ett arbete?

2. Måste Ditt yrke/arbete vara roligt? (kryssa för)

Alltid___ Ibland___Ofta___Aldrig

3. Kan Ditt arbete förändra Ditt liv? (kryssa för)

Alltid___ Ibland___Ofta___Aldrig_

4. På vilket sätt kan Ditt arbete förändra Ditt liv?

5. Är lång utbildning viktigt för Dig, för att få ett drömjobb?

6. Skulle du arbeta om du inte var tvungen? (kryssa för)

Alltid___ Ibland___Ofta___Aldrig

7. Om du har ett 'drömjobb' - varför är detta arbete så bra?

8. Vad är det som gör ett arbete meningsfullt?

Syftet är att ta pejling på ungdomars attityder till arbete och arbetets mening och värde just innan de ska ut i arbetslivet eller påbörja mer yrkesinriktade studier. Frågor om varför vi ska arbeta ställs sällan konstaterar Hans Dahlqvist i en festskrift till arbetslivs- 
och migrationsforskaren Lars Olsson. ${ }^{76}$ Ändå är det så att vilken syn som ungdomar har på arbete är en ödesfråga inför framtiden. Kunskap om ungdomars attityder till arbete är av nytta för både skola, politiker och samhällsdebattörer. Den berättelse som följer handlar både om samtiden och framtiden. Diskussioner om arbetsetik och arbetsmoral är enligt min erfarenhet ovanligt både i lärarutbildning och inom skolans So-ämnen. Det sistnämnda indikerar ju exempelvis läromedelsundersökningen i en av mina berättelser. De berättelser om arbete som ni just nu läser fyller definitivt en kunskapslucka. Tillhör arbetet människans sätt att existera och förverkliga sig själv på eller är arbete egentligen ett livslångt lidande och i grunden omänskligt? Frågan måste ställas. Jag kan inte påstå att jag besvarar frågan i mina berättelser men jag ger visst underlag för diskussion.

I samtliga klasser som undersöktes var jag själv ute och genomförde enkätundersökningen. Jag introducerade den och förklarade vad jag skulle använda resultatet till. Jag berättade om min idé att skriva fyra berättelser om arbete. Att fylla i enkäten var frivilligt liksom att svara på samtliga frågor eller att ge alla uppgifter som efterfrågas $\mathrm{i}$ ingressen.

Sammantaget besökte jag tret-

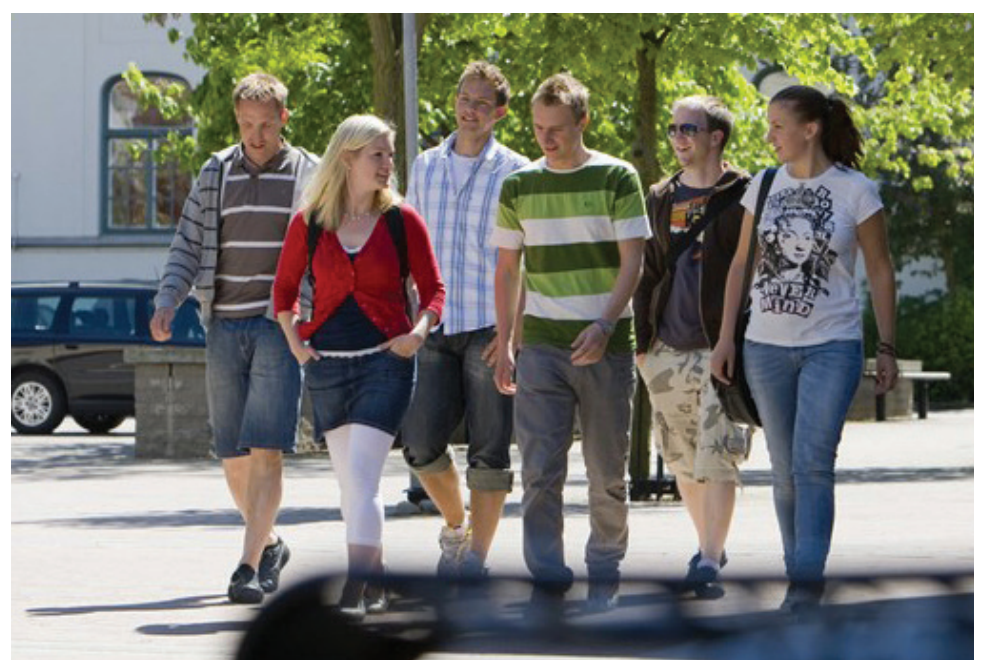

På väg mot arbetslivet (arkivbild). Foto: Jonas Ljungdahl ton gymnasieklasser fördelade på tio avslutningsklasser och tre åk två. Antalet studerande blev 299 elever fördelade på 123 män och 176 kvinnor. Då jag inte fann några avvikelser mellan tvåor och treor så behandlar jag gruppen elever som en enhet. Jag fann heller inte några större avvikelser mellan de klasser som var teoretiska och de som var yrkesförberedande. Jag tar heller ingen hänsyn till elevernas sociala klassbakgrund. Detta är en variabel som eventuellt skulle ha påverkat slutresultatet men som jag tror inte i någon hög grad. Däremot motiveras attityderna av en könsmässig uppdelning mellan män och kvinnor vilket beaktas i analysen. Varje fråga behandlas för sig och ofta tillsammans med analyserande och jämförande kommentar.

\section{Fråga 1: Är det viktigt för Dig att ha ett arbete?}

Eventuellt så kunde frågan följts upp av ännu en fråga som sökt svaret på varför det är viktigt att ha ett arbete. Att så inte görs beror på att jag menar att detta svar dels ges i fråga sju och att det också är så att flera svar på fråga ett faktiskt motiverar varför det är viktigt att arbeta. Det är också nödvändigt att ha ett frågeformulär som är så pass begränsat att den svarande inte känner något motstånd mot enkätens omfattning. En enkät bör ju enligt de flesta bedömares och handböckers uppfattningar inte omfatta mer

76 Hans Dahlqvist 2010:16 
än sex till åtta frågor. Procentsatser som anges har sänkts eller höjts till närmaste heltal. Detta gäller genomgående i berättelsen.

\section{Kvinnor}

Inget bortfall här. Direkta och oreflekterade ja-svar är 108 eller 61\%. Det finns inga nejsvar men två som problematiserar; ”Både och. Vill ju kunna försörja mig. Så det är rätt viktigt men vill inte att jobbet ska ta över mitt liv.” "Egentligen inte, men arbete är en nödvändighet för att kunna ta sig dit man vill i livet. Så ja det är viktigt.”

Pengar: 23 (13\%) kvinnor tar upp pengar som det viktigaste med att arbeta. "Cash is king.” ”Ja, pengar är allt för mig.” ’För att tjäna pengar.”

Försörjning och trygghet: 23 (13\%) relaterar till att arbete motiveras genom förhållandet mellan pengar och försörjning. Pengar behövs "Mest under sommaren nu när man slutar.” För att kunna överleva och ha det bra så måste man jobba.” - och ännu viktigare i framtiden säger en kvinna; för att kunna försörja sig. ”Ja, det är ett steg in i vuxenlivet." pengar är viktigt "så jag kan ha en bra ekonomi och en bra framtid i livet och kunna röra på sig.” Arbete behövs för en fungerande privat ekonomi. ”Ja jag vill inte vara arbetslös efter studenten. Jag vill ha en inkomst å skulle bli för rastlös av att gå hemma hela dagarna.” ’Ja, jag känner att det är viktigt för mig att tjäna egna pengar och känna ett eget ansvar." "Ja det är viktigt! Går frisör för det är det jag vill jobba med." Arbete är ett livselixir för en kvinna som säger; ”Ja, väldigt viktigt. Det är det som man fyller ut sitt liv med och som håller en vid liv." "Det är trygghet att ha en inkomst."

Oberoende/Självständighet/Frihet/Tillfredställelse: Över 10 (ca 6\%) kvinnor tar upp sådant som kan relateras till detta. ”Ja, jag vill kunna tjäna mina egna pengar och inte känna mig beroende av någon annan.” - ”inte leva på någon annan.” ”Att klara sig själv.” ”Ja, vi lever i en värld där pengar styr mycket och då är det viktigt att ha sin egen fasta inkomst.” "Har själv ett extraarbete som hjälpt mig att känna att jag kan köpa för mer än 1000 kr i månaden.” ”Tycker det är skönt att veta att man har pengar när man ska göra något - och har valmöjligheter att göra det man vill.” "Känner inte lika stor press att behöva spara pengar.” ”Ja, annars kan jag ju inte skaffa mig saker jag vill ha, eller klara mig utan stöd från mina föräldrar. Jag vill kunna leva på mig själv och inte på alla arbetande skattebetalare." "Det gäller att jobba sig till möjligheter.”

För arbetets skull och för framtiden: Ett tiotal kvinnor (ca 6\%) berör detta tema. "Ja, det är det. Och det är viktigt att hitta rätt arbete.” Att arbeta är ”Ett sätt att utvecklas och ett bra sätt att få erfarenhet.” Man arbetar; ” självklart för pengar och kunskap”. ”Jag älskar att jobba.” Arbete är bra; "eftersom jag inte tycker om att inte göra något.” ” Ja, det är rätt viktigt, utan arbete har man ingen framtid.” Några lägger ut texten utförligare; ”Ja, det är väldigt viktigt. Annars kommer man aldrig någonstans i livet, man kan ju inte förvänta sig att man får allt serverat på silverfat.” Ja, jag vill mer än allt annat ha ett arbete efter skolan, men också nu. Alltså helgjobb. Jag har sökt över 40 jobb och då själv gått till varje arbete men inte fått ett enda jobb.” 
Det sociala och samhällsnyttan: Ett arbete är viktigt både "socialt och för inkomst." ”Ja, det är svårt att livnära sig och bilda ett eget liv om man inte har ett arbete.” ”Om jag inte har något att sysselsätta mig med så börjar jag klättra på väggarna och så behöver jag de slantar jag kan få ihop.” - "Bra ekonomi och ett socialt liv.” Man arbetar för ”inkomst och social kontakt.”

\section{Män}

Bortfallet på denna fråga var sju män (4\%) som inte svarat. De övriga svaren i deras enkäter tyder dock på att de missat frågan på grund av slarv. En man svarar nja, men även av hans svarsbild framkommer att svaret gäller arbete under studietiden. "Inte i nuläget, men det kan ju ändra sig.” En svarar också något tvetydigt; ”Nej - men en stabil inkomst.” En besvarar frågan; ”Nej, det är däremot viktigt att ha en sysselsättning jag trivs med att göra och jag känner att jag gör något viktigt. Lön kommer i andra hand.” 78 (63\%) män svarar blankt ja utan att motivera svaret ytterligare. Skriver jag nedan inte ut antal svar så är det mindre än fem i nämnda kategori.

Pengar: $12(10 \%)$ män skriver i svaret att det endast är för pengarnas skull; "Ja, pengarna måste in” - "Vad ska man annars leva på.” "Det är viktigt för mig att tjäna pengar." ”Utan pengar klarar man sig inte i dagens samhälle.” ”Ja, tjäna pengar och ha nåt att göra är viktigt.”

Försörjning och trygghet: 5 (4\%) män tar upp försörjningsbördan; "Så jag kan försörja mig själv och kunna ta hand om mig och flytta ut." "Man måste ha en lön så man kan bo och ha mat till sin familj.” Någon problematiserar och svarar ”Ja, för en anledning och det är försörjning. Hade pengar inte varit ett problem är arbete meningslöst.” Någon kombinerar med den trygghet som pengar ger; ”Ja, det är viktigt av den anledningen att man måste ha en stadig ekonomi för att kunna bygga på en trygg framtid.” Leva "ett normalt liv", och "ha något att göra i framtiden.” ”Ja, det är stimulerande samt nödvändigt då vi lever i ett penningsamhälle.”Ja, det ger fast inkomst och en viss säkerhet att man får lön för mödan.”

Tillfredställelse: ”Ja, annars skulle det bli långtråkigt.” ”Det ger en tillfredställelse om du kan vara bra på en sak.” ”Det är väldigt viktigt att känna sig värdefull. ”Och om man inte vill vara fattig och rastlös.”

Det sociala och samhällsnyttan: ”Ja det är väldigt viktigt att ha ett arbete och att göra min del." "Absolut. Det innebär inte bara att jag får pengar att leva på, utan det bidrar även till samhällets funktion.” ”Ja i och med de ekonomiska och sociala aspekterna som ett arbete tillför.”

Kommentar: Det är viktigt att arbeta och ha ett arbete. Så tycker de flesta som fyllt i enkäten. Ungefär $60 \%$ i båda grupperna svarar odelat ja på denna fråga. Att vi arbetar mer för pengarnas skull än för att överleva verkar också vara en talande sammanfattning för studerandegruppen som helhet. Det är också så att fler kvinnor, sett till procent av gruppen som anger arbete för pengarnas skull som det viktigaste resultatet av arbete. Jag 
hade nog förväntat mig det omvända. Svar som berör vikten av försörjning och trygghet är fler för kvinnorna medan själva försörjningsbördan endast berörs av män - då i betydelsen av att ta hand om en familj. Kan synas som en traditionell fördelning där fler kvinnor än män tänker på framtiden i trygghetstermer och tar ett vårdande ansvar men där en del män ser sig som framtida och potentiellt ensamma som familjeförsörjare Att koppla arbete med utvecklingen av personlig frihet och oberoende är mer uttalad i den kvinnliga gruppen. Det syns även som om kopplingen mellan personlig utveckling och arbete samt relationen mellan arbete och framtid är mer reflekterad i den kvinnliga gruppen av informanter.

\section{Fråga 2: Måste Ditt yrke/arbete vara roligt?}

Det finns ett problem med graderingen av angelägenhetsgraden. Vad är förhållandet mellan Ibland och Ofta? Svaret Ofta är sannolikt av de flesta uppfattad som en mer frekvent kategori än Ibland och borde kanske därför placerats före Ibland i ovanstående rad. Fick vid undersökningarna ute i klasserna ett fåtal frågor om detta. Problemet kunde nog ha undvikits om jag hade genomfört ett större antal testenkäter än de två individer som jag provade den på.

Kommentar: Att ett arbete eller yrke alltid ska, eller ofta måste vara roligt är högre för kvinnor än för män $28 \%$ av kvinnorna svara alltid och $45 \%$ ofta. För män är motsvarande siffror $19 \%$ och 32\%. Kanske finns det på så sätt en svag tendens till att män accepterar att även tråkigt arbete måste utföras. Eller att förväntningarna på att ett arbetsliv kan bli roligt och stimulerande är lägre i en manliga gruppen. Däremot är det nästan dubbelt så många män som kvinnor som svarar att ett yrke/arbete måste vara roligt ibland $-47 \%$ män och 25\% kvinnor. Sammantaget skattar män arbetets rolighet lägre än kvinnor. Det är inget av svaren bland kvinnor och män som anger aldrig som svarsalternativ.

\section{Fråga 3: Kan Ditt arbete förändra Ditt liv?}

Att ditt arbete alltid kan förändra ditt liv anser $28 \%$ av kvinnorna och $26 \%$ bland männen. Att det ibland kan vara så tycker 51\% kvinnor och 50\% män. Att det ofta är så får $20 \%$ stöd i de båda grupperna. I stort en mycket samstämmig svarsbild således. Det enda som skiljer sig åt är att 3 stycken män svarar att ditt arbete aldrig kan förändra ditt liv. På så sätt kanske det ändå kan hävdas att det finns en svag negativ tendens till arbetets förändrande förmåga som kan skönjas hos männen. En man skriver i marginalen - ”beror på vad för jobb”. Detta visar på att en intervju hade varit ett lämpligt komplement till enkäten om en mer problematiserad och mångfacetterad svarsbild eftersökts. 


\section{Fråga 4: På vilket sätt kan Ditt arbete förändra Ditt liv?}

\section{Kvinnor}

Eftersom man som regel arbetar en stor del av sitt liv så är det klart att det påverkar dig. Denna grundinställning verkar genomgående.

Pengar: De kvinnor som på något sätt för fram att pengar är angeläget är relativt stor 21\%. Att arbeta kan ge "bättre ekonomi", "bättre boende och bättre levnadsstandard". Arbete ger "pengar som kan omsättas i andra saker och i att göra saker". "Det (arbetet) avgör hur mycket pengar man tjänar och det avgör vad man kan göra”. ”Om jag tycker arbetet går bra och jag tjänar bra med pengar”. "Inkomst kan få livet att gå enklare”.

Arbetskamrater/Vänner/Kompisar: "Arbetskamrater och sysselsättning är positivt” Man får nya vänner genom arbetet. "Träffar nya människor, får rutiner i vardagen”. Drygt en handfull kvinnor pekar på detta som det viktigaste incitamentet på hur arbetet förändrar livet - man får nya kompisar. Detta kopplas ibland samman med nya erfarenheter i allmänhet och blir en större grupp på omkring $20 \%$.

Flytt: Att arbetet förändrar ens liv vid "flytt" till annan ort eller - där jag ibland anar en hotbild " - om man måste flytta". 11\% av kvinnorna tar upp detta som huvudpunkt i hur arbetet kan förändra livet. Nya utmaningar "flytta från Kalmar " - Arbeta på andra ställen

Utveckling/Möjligheter/Erfarenheter/Förändringar: De kvinnor som berör dessa kategorier skriver ofta längre svar än några ord eller en kort mening. Arbetet utvecklar dig som människa/person. Du lär dig ”ta ansvar” och ”växa som människa”. ”Man utvecklas kanske som person inom vissa yrken och träffar människor som påverkar en”. Flera skriver "Få mig att utvecklas som person” - ”Det får mig att ständigt utvecklas”. "Utvecklar min förmåga att tänka kreativt samt utvecklas socialt” - "Man utvecklas både socialt och mentalt av ett arbete”. Arbetet skapar förutsättningar för livet - Påverkar boende, familj - det ger upphov till nya kontakter och nya erfarenheter och man lär sig ständigt nya saker.

Arbetet ger nya möjligheter. "Man träffar nya människor, lär sig nya saker och arbetet ger nya saker. På så sätt förändras mitt liv”. ”Man lär sig nya grejor - får erfarenheter att klara av saker". ”Det är erfarenheter som formar en människa.” Det "ger upplevelser för livet”. ”Det kan få mig att må bra, bli en annan människa och självklart att nå mina mål i livet." "Arbete förändrar levnadsstandard men också det allmänna perspektivet som du ser på saker.” Möjligheterna kan också vara målinriktade - "Man får kunskap och man lär sig alltid något nytt och detta kan göra att du kommer dit du vill.” "Om man mår bra med det man gör och lär sig nya saker du har nytta av”. ”Du formas av nya händelser och upptäckter.” "Man blir pushad och mår bra av att jobba.”

Självständighet: "Nya erfarenheter, kunskaper, kompisar mm lära sig att klara sig själv" "Försörja sig själv och bli självständig” - "försörja sig själv och bli oberoende”. "Egen lägenhet o starta eget liv utan sina föräldrar". Arbete ger "självförtroende och inspiration”. "Man får råd att skaffa barn och familj”. 
Existentiella tankar/Självinsikt: "Vissa jobb gör dig till en bättre människa”. ”Du får ett socialt nätverk." "Personlighet, vanor, människor man träffar gör att du utvecklas som människa" - "det ger mening åt tillvaron”. Arbetet "Ger insikt om livets mening, eller om det har någon mening." - ”Arbetet styr mina vanor-det blir en livsstil”. ”Att lära sig se alla människor och respektera dem för vad de är." "Det man har blir en stor del av ens liv rent tidsmässigt. Sedan tror jag att man lär sig mycket om sig själv av att arbeta.” "Det är viktigt att känna arbetsglädje." "Välbefinnande om man har ett arbete som man trivs med”. "Arbetsliv och yrkesliv hänger samman”. "Yrke - arbetskamrater - arbetstider - allt detta förändrar livet - liksom ansvar och arbetsbelastning."

Kritiska tankar: Man måste arbeta "för att få råd att leva men kan också få mig sönderstressad". Så att arbeta för flera fram som både bra och dåligt. "Det beror på vilket jobb du har.” Det kan ge arbetsskador. ”Beroende på vad du arbetar med så påverkas ditt liv - Det kan ge ett bättre/sämre liv." ”Göra en glad och ledsen”. ”Kan betyda både positiva och negativa upplevelser ”. Några är odelat negativa ”sämre tror jag” - "Vet ej om det kan förändra ditt liv men jag tror att det kan det”. Några för fram faror med att gå upp för helhjärtat i arbetet: "Om man brinner för det man arbetar med så kan jobbet bli livets viktigaste del och man glömmer då bort andra viktiga delar av livet ex familj, vänner.” Det kan vara ett krävande yrke med mycket tid på jobbet så trivseln har betydelse - ha ett roligt jobb.

Enkäten visar för kvinnor upp sex blanka svar vilket motsvarar 3\%.

\section{Män}

En iakttagelse är att män som regel ger mer kortfattade svar.

Pengar: Männens svar handlar mer om pengar än kvinnornas. Mycket pengar ger mycket frihet och fler möjligheter. Ekonomiska möjligheter ger status vilka somliga likställer med livskvalité. "Cash. Man!" 'Det gör att jag kan försörja mig själv och kanske min familj. Vilket leder till att jag har valmöjligheter.” Direkt pengarelaterade svar utgör $37 \%$ av männens svar.

Arbetskamrater/Vänner/Kompisar: Genom att få nya arbetskamrater och träffa nya människor så utvecklas man själv som människa. Detta är personlighetsutvecklande. "Jag får en positiv syn på vissa saker och på människor" - "det ökar förståelsen”. ”Arbetskamrater och miljöer kan ändra ens personlighet och värderingar." 28\% relaterar svar till dessa kategorier.

Flytt: 6\% talar om flytt som en möjlighet eller eventuellt ett hot. "Tvingas till anpassning vid flytt till nya platser."

Utveckling/Möjligheter/Erfarenheter/Förändringar: Att arbeta gör att "du mår bättre psykiskt". Du får nya erfarenheter, 11 \% meddelar detta, du får valmöjligheter och du "får perspektiv på livet”. Du kan göra nya saker och lära sig nya saker och en handfull män talar om de sociala möjligheterna som kan förändra ditt liv. En handfull talar om färdigheter och kunskap som förändrande krafter. Det kan förändra din person - ”Du skulle liksom inte vara samma person om du inte haft det jobbet”. ”Det blir en mer rutin- 
bunden vardag på gott och ont”, men om man "trivs” och har "roligt” så kan det förändra livet. "Man hoppas att det kan det”. En handfull talar om att man måste anpassa sig efter sitt arbete. Men förändringar - "beror också på vilket arbete du har.” Man blir självständig och får ett eget boende. "Man kanske tvingas att anpassa sig efter jobb och karriär, med familj osv”. "Eget boende gör en självständig”. Detta leder oss till nästa kategori.

Självständighet/Existentiella tankar/Självinsikt: Arbetet fyller livet - "Man får något att göra”. Själva arbetet kan också förändra en person till det bättre. Man "blir en bättre människa” om man "gör en viktig samhällsinsats”. "Man känner glädje om man gjort något”.

Kritiska tankar: Några talar om de skador och olyckor som arbete kan ge upphov till. Beroende på vilket arbete man har. Ett arbete har både "positiva och negativa" sidor. "Hinner inte göra det jag vill” - "Tar min tid” - "Inte lika mycket fritid”. Man kan "bli arbetsnarkoman".

Enkäten visar för män upp nio blanka svar vilket betyder 7\%. Därtill finns fyra Vet ej svar.

Kommentar: Männens kortare svar kan ställas mot kvinnornas mer utförligare. Det kan också påpekas att inga särskilda reflektioner görs om förhållande mellan kroppsarbete och intellektuellt arbete förutom allmänna påpekanden om att det beror på vilket arbete man har. Pengar syns viktigare för män som har 37\% mot 21\% för kvinnorna. Männen för i högre grad fram kompisars och arbetskamraters betydelse $28 \%$ för män och 20\% för kvinnor. Fler kvinnor tar upp en förändringsfaktor som flytt - 11\% mot 6\% för män. Fler kvinnor tar upp perspektiv som kan kategoriseras ha existentiell natur. Männen har mer än dubbelt så hög andel blanka svar, 7\%, jämfört med kvinnornas 3\%.

\section{Fråga 5: Är lång utbildning viktigt för Dig, för att få ett drömjobb?}

Även denna fråga kan i efterhand ses som något luddig då den ger en svarsbild med kommenterande nej och ja svar som kan vara knepiga att kategorisera. 8\% av kvinnorna ger dock svaret ja utan att precisera närmare och 14\% säger nej. För männen är det $21 \%$ som svarar ja och $46 \%$ nej. En stor skillnad mellan kvinnor och män. De kvinnor som säger nej brukar tillägga något. "Nej! Fast det beror på, det finns ingen direkt utbildning om man vill bli fotbollsproffs eller liknande.” ”Man kan få sitt drömjobb utan utbildning.” - är väl också ett nej-svar. ”Nej, det är inte viktigt men det är viktigt att testa på olika saker för att få med sig mycket i bagaget.” ”Nej, det är inte längden på utbildningen som spelar roll. Det är om den ger dig som studerar ngt tillbaka t.ex. jobb, erfarenhet, lärdom...” ’Nej, jag tror inte på att utbildning alltid är rätta vägen. Erfarenhet och vilja går före skolbänken helt klart!" - "erfarenhet och kontakter är viktigast." ”Nej, jag behöver bara tålamod och uthållighet, samt fantasi.” Det är betydligt färre män som kommenterar sitt nej-svar. ”Nej. Du ska inte behöva arbeta ut dig innan du börjar arbeta." ”Nej, bara man trivs och mår bra och får andra att må bra det är Prio ett.” ”För mitt drömjobb krävs inga jätteutbildningar innan. I utlandet ingår utbildning i jobbet.” 
En man menar att ”Man kan ha ett drömjobb utan lång utbildning beroende var man sätter ribban."

En handfull kvinnor preciserar utbildningstiden till ungefär tre år (två män preciserar) och 7\% kvinnor (3\% män) svarar blankt. I några svar har jag korrigerat stavfel både för kvinnors och mäns svar.

\section{Kvinnor}

Anpassning: En stor grupp kvinnor (60\%) menar att man måste anpassa sig efter yrkets krav. ”Jag skulle aldrig välja arbete och tänka på utbildningen först, är det kort så är det bra men är det långt så får man kämpa en längre tid innan man är klar.” ”Alla har vi olika drömmar och olika arbeten kräver olika utbildningslängd.” ’Om det verkligen är mitt drömjobb det handlar om så spelar det ingen roll om vägen dit är lång.” ”Jo, annars kan jag inte bli det jag vill.” Någon svarar; ”Nej, det behöver det inte vara.” Svaret indikerar att vederbörande kan tänkas acceptera en både längre eller kortare utbildning. Rena nej-svar är ovanligare bland kvinnor. De motiverar ofta sitt nej så att det hamnar i en kategori där de tycks ha en beredskap att anpassa sig. ”Nej, ett drömjobb behöver inte ha lång utbildning, det är individuellt vad man har för drömjobb.” ”Nej, ju kortare desto bättre.” ”Det är värt det även om det tar ett tag.” ’Det beror ju på lite. En lång utbildning ger mycket kunskap vilket är viktigt men det skulle ju inte vara fel om man inte behövde så lång utbildning.” Eller som en kvinna uttrycker sig - ” men idag krävs rätt lång utbildning för det mesta...” Flera talar om att kämpa - ”Men drömmer man om något är det ju klart att man kämpar.” - ”spelar ingen roll hur lång utbildningen är - har man ett drömyrke så har man och då måste man kunna kämpa.” ”Det handlar om självförverkligande. Det är nog värt det i slutet. Hur lång utbildningen är spelar ingen roll.” ”Jag tycker att det känns viktigt med utbildning då man rankas högre och lättare tar sig framåt på karriärstegen. Men det allra viktigaste är drömmarna och viljan, man kan det man vill.”

Några är mer tveksamma eller svarar helst inte. ”Beror på hur lång utbildning mitt drömjobb har.” ”Nej, beror på vad jag vill bli. Om man får jobbet utan utbildning är det ju perfekt (pengar snabbare)” ”Jag skulle ju helst få ett drömjobb utan att behöva gå i skolan efter gymnasiet." - eller "Helst utan utbildning för då är det lättare att ändra yrkesinriktning." "Helst kort utbildning. Learning by living."

Exempel på avvikande svar är när någon problematiserar och ställer utbildningstiden mot den lön man förlorar på lång utbildning. Andra är vilsna; ”Jag vet inte riktigt, om man har viljan och fantasin och även en del kontakter så nej, då tycker jag inte det.” "Man kan nå dit man vill om man är tillräckligt målmedveten och intresserad. Långa utbildningar kan få glädjen att försvinna."

\section{Män}

Anpassning: En betydligt mindre grupp av män (26\%) säger sig vilja anpassa sig efter yrkets krav. Mindre än hälften så många som kvinnorna måste sägas vara en anmärk- 
ningsvärd skillnad. Männen ger som regel också betydligt mer kortfattade svar. Svaren är också något mindre entusiastiska. "Om det är det som krävs". - "om det är nödvändigt för att få ett jobb man gillar ” - "eller få bra med pröjs." "Beror på ju. Men självklart är utbildning viktigt." - "om man får ett bra jobb." ”Ju mer man får lära sig, ju större chans att man blir attraktiv i arbetsgivarens ögon." "Ja om man verkligen vill ha ett speciellt jobb men om man drömmer om att jobba på ICA osv, så kanske man inte behöver plugga så mycket." "Beror helt på vilka målsättningar man har och vad man vill jobba med." En man för fram trivseln som en drivkraft; "Det viktigaste är att trivas med sitt jobb, om det så krävs en lång utbildning." ”Jag studerar för att lära mig IT, det blir som en hobby att studera det man tycker är kul så man kan jobba med något man vill.” En lång utbildning är viktigt; "så jag får jobba med det jag älskar." Någon vill helst inte utbilda sig; "Hade helst inte velat utbilda mig så länge, men det är ett måste." Det finns tveksamma; "Både ja och nej. Det beror på hur du ser det." "Nja jag tror jag ska utbilda mig men hittar jag ett bra jobb på annat sätt så jobbar jag hellre än att utbilda mig." Utbildning ”inte nödvändigtvis. Jag har inget speciellt drömjobb." "Det är viktigt eftersom det krävs av samhället men för mig själv har utbildningen mycket liten betydelse." Det finns alternativ till utbildning; "Nja, det beror på, har man många kontakter så kan man fixa allt. Men det är alltid bra att ha lång utbildning. Ser absolut inget negativt med det." Så finns det de som raljerande säger; "Bara jag får cash bror!"

Kommentar: På frågan om lång utbildning är nödvändig för drömjobbet ges en svarsbild som visar att det verbalt finns ett övertag för kvinnorna som lägger ut texten på ett mer engagerat och fantasifullt sätt än männen. Det är $8 \%$ av kvinnorna som svarar ja utan utvikningar och $21 \%$ av männen. Kvinnorna nej svar utgör 14\% och männens $46 \%$. Det verkar som om männen är mer polariserade mellan enkla ja och nej och av lathet eller av ointresse hellre svarar enstavigt. Kvinnorna är inte lika benägna att förenkla svaret till ett ja eller nej. Samtidigt är en relativt stor grupp män medvetna om att vägen till ett drömjobb betyder hårt arbete men nästan hälften av männen tycker inte att lång utbildning är viktig för drömjobbet. Kvinnorna syns ha en större vilja till att anpassa sig efter yrkets krav - krävs utbildning så tar de det - 60\% kvinnor tycker så men bara $26 \%$ av männen. Jag tolkar det som om kvinnorna har en bättre verklighetsbild och är mer villiga till en extra arbetsinsats för att komma dit man vill - få ett drömjobb. Männen verkar inte ta utmaningen med lika stort allvar. De har en klar låt gå attityd och saknar kvinnornas engagemang.

\section{Fråga 6: Skulle du arbeta om du inte var tvungen?}

Resultatet på denna fråga visar att ett större antal män alltid vill arbeta, 23\% jämfört med 18\% kvinnor. Fler män svarar också att de aldrig vill arbeta. Männen har där 10\% när kvinnorna har $2 \%$. Polariseringen hos männen mellan alltid och aldrig är mer uttalad hos männen. Oviljan hos $10 \%$ av männen att arbeta är anmärkningsvärd. Andelen kvinnor som säger sig vilja arbeta ibland är 58\% jämfört med 55\% för män. I stort lika 
procentvärde således. Däremot vill fler kvinnor arbeta ofta $-21 \%$ av kvinnorna och 12\% av männen.

Kommentar: Som helhet ett snarlikt resultat i de båda grupperna. Det är signifikativt fler kvinnor som säger sig vilja arbeta ofta och fler män som aldrig vill arbeta om de inte var tvungna att göra så. Resultatet visar också att de allra flesta (mer än hälften i båda grupperna) vill arbeta ibland. Sammantaget i de båda grupperna är det fler som vill ar-

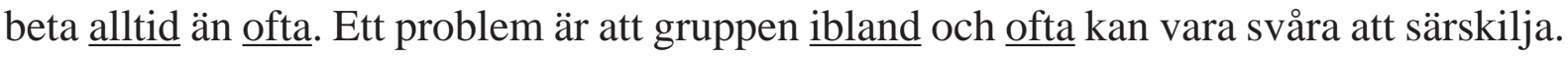
Man kan fråga sig vad som är skillnaden mellan dessa kategorier. Ofta är som svar kanske uttryck för en acceptans av en större arbetsfrekvens än vad svaret ibland är? Slutsatsen är att de flesta är positiva till en "lagom" arbetsinsats vilket svaret ibland indikerar. Kvinnogruppen har en något mer positiv inställning till en ”lagom” arbetsinsats. Om vi för samman kategori ibland med kategori ofta får kvinnorna 79\% och männen 67\%.

\section{Fråga 7: Om du har ett 'drömjobb' - varför är detta arbete så bra?}

\section{Kvinnor}

Trivsel/Roligt /Glädje: Gör man något man är intresserad av och har nått ett uppställt mål, "det man drömt om och det man är bra på att göra” så "mår man bra” och "har kul på jobbet". Så många som 69\% kvinnor berör dessa kategorier. Arbetet är så bra; "För att jag trivs på jobbet, har bra arbetstider o bra arbetskamrater. Man känner ingen ångest, utan man kan vara sig själv och känna sig trygg i det.” Arbetet "gör att jag får vara glad och lycklig på mitt jobb o förhoppningsvis göra andra glada. Det är viktigt att man trivs.” ”För det är anpassat efter vad jag vill, tycker om.” ”För det är något jag tycker är intressant. Något jag tycker verkar roligt. Pengarna har ingen betydelse utan intresse.” "Mest att man trivs och mår bra." "För då trivs man och ser fram emot att gå dit. Mitt drömjobb delar dessutom med sig utav glädjen. Man lär sig om allt och alla personligheter." ’Förhoppningsvis är det jobbet som jag vill ha mer än något annat som i mitt fall är musik och dansjobb. Det ger mig glädje i vardagen och det är musik/dans jag älskar mer än något annat.”

Svar som tar upp att göra andra glada och hjälpa sina medmänniskor på ett meningsfullt sätt har också sina förespråkare i kvinnogruppen. 11\% tar upp detta. "Jag skulle känna mig lycklig. Skulle känna att det jag gör är viktigt och andra skulle tycka att det var bra." "Trivsel, känsla av engagemang, trevliga arbetskamrater, möjlighet att göra skillnad på något sätt och känna att man hjälper folk.” "Hjälpa personer och visa dom att de aldrig är ensamma.” "För att det ger mig en möjlighet att göra det jag vill, att påverka och hjälpa, och det skulle göra mig motiverad."

Bland kvinnorna tar14\% upp pengar, som en enskild angelägenhet till att arbetet är bra eller i kombination med andra kategorier. ”För då får jag jobba med det jag vill hela dagarna å ha kul å förhoppningsvis en bra inkomst." "'Det är något jag brinner för, för något som gör mig glad och stolt, jag tjänar bra.” ”Man tjänar mycket bra och arbetet 
blir inte ett måste. Utan mer som en betald hobby. Då har man fått sitt drömjobb.” "Är man lycklig mår man bra”. "Behöver även en lön att du klarar dig och inte behöver spendera varje månad med att tänka på hur man ska få ihop till hyran.”

Arbetskamrater/Nya människor/Kollegor: En relativt stor grupp berör att arbetet känns bra tillsammans med andra. 17\% anger detta som viktigt. "För då har jag lyckats, jag har kommit långt $i$ livet. Jag som ska bli frisör skulle bli så glad om jag fick en heltidstjänst efter gymnasiet. framtiden är räddad, det är kul att gå till jobbet och man får lära känna nya människor.” Arbetet är bra - "För att man arbetar med underbara människor."

Några få kombinerar med arbetets sociala funktion. "För att få träffa nya människor och vara social, det gör att man skrattar mer under dagarna. Att få arbeta med händerna och göra folk nöjda.”

En handfull svarande tar upp vikten av att arbetet är kreativt och att det därigenom är viktigt och intressant. "Det vore lite av en dröm att få jobba med något kreativ (författarskap, ungdomsprojekt, marknadsföring etc) för att jag tycker det är roligt och intressant.” ”Det är spänningen, möten med människor, kreativitet och glädje som lockar.” Lika många talat om att arbetet är bra om det är tryggt.

Arbetet ska vara varierat och innehållsrikt tycker en annan grupp om fem kvinnor. ”Jag har inte riktigt kommit fram till mitt drömjobb än. Men jag gillar att ha dagar som inte är sig lika."

Ett par stycken lyfter fram frihet och självständighet och kunna påverka; "För det är jag som är VDn och får jobba med det jag vill jobba med." "Jag skulle vilja kombinera mina drömmar och göra allt lite när jag vill” - "arbeta med det jag vill”. ”Jag vill ha ett arbete där jag själv kan bestämma arbetet. Jag kan jobba hemma och planerar dagarna själv. Som exempelvis frilansjournalist eller utrikeskorrespondent." ”Ett arbete där jag kan förändra."

Arbetet gör dig till den du är. Du blir bekräftad och utvecklas. Några informanter är inne på denna tanke - "andra gillar vad man gör”. ”Jag vill bli något inom pedagogik. Hjälpa ungdomar som har problem med droger ex.” ”Om jag aldrig har ångest över att det är söndagskväll så har jag nog mitt drömjobb. Där jag ständigt utvecklas men har tid till fritid där yrket inte ständigt finns i mina tankar."

Några svarar också att arbetet är bra just för att det är en Dröm.

Några har inga drömjobb. ”Har inget drömjobb för tillfället. Men kan ju dock säga att linjen jag valde att gå i nian inte är den jag skulle valt nu.” Några svarar inte på frågan eller relaterar till hur det är just nu och berättar att man inte vet vad man ska bli och inte har något drömjobb eller att man just nu extraknäcker på helgerna.

Några specificerar yrket; polis, lärare, socionom, frisör, arkitekt, läkare, stylist, mäklare, dansare.

Blankt lämnas av 7\%. 


\section{Män}

Trivsel/Roligt/Glädje: Denna kategori samlar svar från 55\% av männen, ofta i kombination med pengar. ”Ett arbete jag tycker är roligt. Jag har fria arbetstider. Tjänar bra.” Arbetet är bra för att man tycker om det, är intresserad av det eller tycker det verkar intressant och kul. "Roligt, mycket pengar, intressant." ”Man älskar gå till jobbet. Man trivs med det man gör." "Gör något jag tycker om.” ”Det man är intresserad av och då blir det kul." "Om man njuter av det och tycker om det varje dag." "Har men ett arbete man älskar blir det mer av en livsstil än ett jobb.” ”Finns ingen ångest när jag kliver ur sängen.” Några kombinerar med goda arbetskamrater - "Därför det rockar (därför du jobbar med något du gillar och med folk du trivs med)." ”Det skulle vara ett jobb där man trivs med sin arbetsuppgift, sina arbetskamrater, bra överens med chefen och hyfsat betalt."

Pengar: Detta är en markant kategori hos männen. Det är 31\% som för fram pengar som en enskild eller delad variabel på att ett drömjobb är bra. "Mycket cash!" "För jag blir rik och lycklig.” "Allt handlar om pengar, mycket pengar så är allt bra/Mycket ledigt."

Betydelsen av arbetskamrater, träffa nya människor tycker 4\% av männen är betydelsefullt för att ett arbete ska vara bra. ”Poker. Där träffar jag nya människor. Det ger stora pengar och det gör kändisskap. Jag tänker inte arbeta 08-14 varje dag och ha ett mediokert liv."

Hjälpa andra i sitt arbete gör det till ett drömjobb för 4\%. "Utlandstjänst i Afghanistan. Jag vill vara någonstans där man får hjälpa till och gör skillnad.” ”Lyckas med något som kan vara bidragande till ett bättre samhälle.” Någon kopplar till självförverkligande. "Känslan av att få göra något som betyder något för andra och för mig själv.”

Om frihetens betydelse talar $7 \%$ av männen. Det är om friheten att själv välja sitt arbete - "Fritt under ansvar" - "Man gör vad man vill”. "Man får frihet, man kan själv bestämma. Inkomsten är väldigt bra, man känner sig nöjd helt enkelt.”

Två svarande nämner status - "Eftersom jag tjänar väldigt mycket och får hög status genom mitt yrke.” Kreativitet och självständighet berörs - ”För jag kan vara med och ändra på något utan att trampa på någon annan, och jag kan kombinera jobb och livsstil och det är viktigt." Stimulerande används som ord av tre män - "Stimulerande miljö där mina kunskaper och erfarenheter uppskattas.” Någon talar om den nytta man gör och en annan om målet för arbetet; "Man har uppnått det man satt ut för att uppnå.” En menar att drömarbetet ska var "utmanande".

Några svårkategoriserade svar är "Ett hederligt arbete, inte som ett "pappersarbete." Faktiskt det enda svar som pekar mot att ett kroppsarbete är att föredra framför andra val. En studerande som går ett yrkesprogram svarar pragmatiskt ”Jag har inget drömjobb. Jag vill arbeta som elektriker för att jag vill och det kommer alltid att behövas elektriker.” Någon svarar undvikande ”Det är så udda” och ”Inte jobba helger” eller att jobbet är ett drömjobb ”För att det är det jobbet man strävar efter.” 
De som specificerar vill tre bli fotbollstjärnor och två elektriker, regissör, radiopratare, läkare och författare.

Blankt eller vet ej ges som svar av $11 \%$.

Kommentar: Vi kan slå fast att olika former av arbetsglädje framför allt uttryckt som trivsel är viktigt bland både kvinnor och män. Det är viktigt för $69 \%$ av kvinnorna och för $55 \%$ av männen.

Att göra andra människor glada genom den medmänskliga hjälp man kan ge stöds av11\% kvinnor och av 4\% män.

Inställningen att arbetet är ett verkligt drömjobb om det genererar mycket pengar förs fram av 14\% kvinnor. Där finner vi en betydligt större manlig grupp som omfattar $31 \%$. Mer än dubbelt så stor. Männen föredrar tydligen i hög grad hårdvaluta som ett kriterium och mätare på varför ett arbete är bra.

Att föra fram arbetskamraters betydelse för drömjobbet och glädjen i att träffa nya människor och kollegor omtalas som viktigt av $17 \%$ kvinnor och endast av 4\% män.

Det egocentriska draget, om nu frihet i betydelse av att få göra som man vill är ett sådant, visar sig som 7\% hos männen och endast några få procent inom kvinnogruppen.

Blankt svar ges av 7\% kvinnor och $11 \%$ män.

Den mest anmärkningsvärda skillnaden är att pengar är så starkt relaterat till ett drömjobb i den manliga gruppen jämfört med kvinnorna.

Att umgås med kollegor och träffa nya människor är en kategori som är starkare uttryckt av kvinnorna. Över huvud taget verkar det som att vikten av relationer med andra människor är mer markant inom kvinnogruppen i mitt material.

Friheten att gå sin egen väg uttrycka starkare av männen. Denna frihet kan ibland tolkas som en slags aningslös ansvarsbefrielse.

Med ett undantag i de specificerade yrkessvaren är det inte något av enkätsvaren som tar upp ett traditionellt kroppsarbete som eftersträvansvärt.

\section{Fråga 8: Vad är det som gör ett arbete meningsfullt?}

\section{Kvinnor}

Hjälpa/förändra/påverka/glädja: Svaren handlar om att vara uppskattad genom att verka i samhället för förbättring. Det kan vara att "verka positivt för andra och för en själv"- hjälpa de utsatta till en bättre framtid. "Om det har någon innebörd för något/ någon annan. Om det är till stort värde av något/någon. Om det är viktigt för en framtida förändring." Arbetet är meningsfullt; ”När det hjälper andra människor runt världen, inte bara en själv.”

Det skulle kunna tänkas att religiösa värderingar finns med i denna svarsbild - men så är inte fallet. Det finns ett svar som talar om moral och etik. "I första hand är det meningsfullt så länge jag gör något som är meningsfullt för mig med pengarna som jag tjänar. För att arbetet i övrigt skulle kännas meningsfullt för mig vill jag bidra med något för 
samhället, samt i största möjliga mån följa mina moraliska och etiska principer,( t.ex. slippa jobba med kött då man är vegetarian).”

Arbete är också meningsfullt "Om du kan hjälpa samhället, de dåligt ställda i vår värld." "Att man hjälper någon/något!" "Ett arbete där jag kan förändra." "Att göra något som kan hjälpa andra människor. Samtidigt som man tycker om och brinner för sitt arbete."

Vissa av svaren kommer att kategoriseras i flera grupper. Man kan i samma svar tala om pengars betydelse, ge hjälp åt andra eller att man gillar sitt arbete. ”Man får en bättre ekonomisk grund, man träffar människor, och att man känner att man är en del av samhället och man hjälper till i samhället." "Se andra bli glada över det arbete som man utför och gör att man vill sträva vidare o utvecklas inom arbetet.” ”Det är dels de ekonomiska bitarna. Men man bidrar även med något för samhället plus att man växer och utvecklas i sig själv.” ”Du gör något positivt för andra, samhället eller miljön. Om du förändrar något till det bättre.” ”Gör något meningsfullt för andra och för mig - inte bara sitter och pillar navelludd.” Man vill glädja andra och känna sig behövd och uppskattad.

"Man gör en tjänst för hela samhället.” ”Vi är alla en del av ett fungerande samhälle.” ”Att man gör sin del i samhället o att man inte lever på andras pengar. Känslan av att man gör något vettigt i stället för att ligga hemma o göra ingenting. Jag tycker att alla är skyldiga en del i samhället.” ”Ett jobb blir meningsfullt när man tycker att det gör mening. När man märker att det förändrar något att arbetet man har gjort syns och att det även påverkar andra människor." Denna grupp utgör bland kvinnorna 31\% och är bland de mest välformulerade svaren. Dessa svar är ibland svåra att kategorisera; ”Pengar, att man hjälper till att skapa en förändring. Man arbetar med någonting som har en mening."

Genom att Göra ett bra jobb/Göra nytta gör "man skillnad”. Bland kvinnorna talar $15 \%$ om detta i någon form. Genom ett betydelsefullt och väl utfört jobb gör man skillnad för andra. "Både jag och människor omkring mig har nytta av det arbete jag gör.” "Att ens jobb faktiskt behövs och uppskattas tror jag är väldigt viktigt." "Att man gör sitt arbete bra, får beröm och får bra betalt. Att man är aktiv, framåt och vill prestera.” ”När man får bra respons och att någon uppskattar vad man gör.” ”Att man har möjlighet att göra skillnad om så bara för en person.”

Att arbetet är roligt och att man trivs för flera fram, ofta i kombination med att man helst vill arbeta i gemenskap tillsamman med arbetskamrater/medarbetare. ”Kompisarna. hur man jobbar, var man jobbar och en massa annat." "Att man trivs med det och känner att man varje dag vill gå till jobbet, man måste även ha bra kollegor omkring sig. När arbetet är som bäst och mest meningsfullt är när man känner att man har hjälpt till och få dem att må bra.”

Det är viktigt att "umgås och träffa folk” i sitt arbete. Arbetet är meningsfullt "När man får ut mer än pengar, det kan vara att man arbetar som volontär, träffar roliga människor, har ett bra sällskap.” ”Att jag får bidra med min åsikt. Men också bra medarbetare 
som gör jobbet extra roligt och som gör att man vill gå dit varje dag." "Bra kollegor och positiv arbetsställning."

"Att man gör det man vill, träffa nya människor, få mera kunskaper. Förhoppningsvis lära sig av sitt jobb och inspirera andra människor." "Om du och andra kan ta del av ditt arbete."

Det finns innehållsrika svar som; Du skaffar nya kompiskretsar och om du trivs där mår du bra och det känns meningsfullt. Att arbeta är också en social grej som är väldigt nyttig för alla människor." "Man blir så nära sina arbetskamrater att de också blir viktiga utanför arbetet." Det är 58\% av kvinnogruppen som berör kategorier som handlar om gemenskap i sina svar.

Att utvecklas och växa genom sitt arbete berörs av 10\% kvinnor. "Hjälper men andra till att må bra så utvecklas man. Så blir jag nöjd. Det är nog det viktigaste.” "Utvecklingsförmågan på arbetet.” Någon punktar "Lönen - Motivationen - Målen i livet Lyckad karriär." "En okey lön så att man kan försörja sig, en god miljö och bra arbetskamrater, såklart ska det vara roligt med."

Tre svar tar upp betydelsen av att bli vuxen, självständig och att skaffa familj.

Att arbeta är meningsfullt för att det är "intressant, lärorikt, omväxlande." Själva arbetet är meningsfullt. Det är $16 \%$ som tangerar detta i sina svar. Arbetet blir meningsfullt "Om man älskar att arbeta och tycker att man är bra på att göra det man arbetar med."

"Man har något att göra varje dag." Det ger en "struktur i vardagen och det är något som jag tror är meningsfullt.”

Någon talar om att få en bra position i livet och någon om den lärdom som ett arbete kan ge. Ett svar säger att "bra arbetsmoral och bra arbetsmiljö" gör arbetet meningsfullt. "Arbetet ger stimulans om man får ut något av det."

Att "få in pengar så man har råd att leva", ingår i tema pengar eller inkomstens betydelse som berörs av 35\% kvinnor. Svaren handlar om att få ett arbete som ger bra betalt så man kan försörja sig utan problem. Den egna ekonomin och eget förvärvade slantar lockar. "Pengarna såklart!" "Men bara den saken att man får en inkomst gör att det känns meningsfullt och att man trivs och tycker det är roligt.” Ett svar som hamnar i olika kategorier.

Andra svar som också är av sådan natur är "Att man tex gör ett bra jobb, bra service med nöjda gäster på restaurangen jag jobbar på. Samt att jag tjänar pengar så jag kan unna mig på fritiden.” ’Träffa människor o få in pengar.” "Känslan av att veta att man förtjänat pengarna man tjänar o att kunna göra något som man vet man gjort sig förtjänt av."

Icke svar eller blankt utgör 3\% - även om ett svar som "Vad innebär meningsfullt?" också bär sin mening.

Några svar anknyter till sin kommande yrkesroll. En som går "stylingutbildning" säger om det meningsfulla arbetet " - kunder, kollegor, roligt, pengar, träffa nytt folk.” En 
blivande frisör säger ;”Att alla arbeten behövs, som frisör t.ex. alla måste väl klippa sig någon gång.” En som går ett omvårdnadsprogram säger; "Att få tillbaka det man gjort, t.ex. beröm från vårdtagare.” Jag kan inte se någon skillnad i attityder mellan de som går teoretiska program jämfört med de som går mer praktiska förutom att de som ovan vid ett fåtal tillfällen refererar till sitt framtida yrke.

\section{Män}

När männen svarar på vad det är som gör ett arbete meningsfullt så finns det ett par kategorier som är betydelsefulla, dock inte riktigt i samma utsträckning som i kvinnogruppen. En av dessa handlar om att hjälpa, förändra och påverka. Man vill glädja andra men också känna sig uppskattad. Intentionen är att bidra till samhällsbygget på ett positivt sätt. Denna kategori får hos männen 24\%. "Jag vill i framtiden arbeta, bidra och göra min plikt för mänskligheten.” "Det påverkar samhället, (håller mig sysselsatt) och genererar pengar.” Flera av svaren faller inom olika kategorier och sorteras därefter. "Man gör något som kan uppskattas hos folk." "Ett meningsfullt arbete har som syfte att hjälpa andra människor på olika sätt.” Ett arbete känns meningsfullt; ”När du påverkar någon eller ditt eget liv positivt. Du har chansen att göra viktiga saker.” Ett arbete ska ha "variation kreativitet man behöver känna att man åstadkommit något, för sig själv och andra." "Känna att man är delaktig och kan hjälpa att utveckla det företag du jobbar med.” Det är meningsfullt; "När man vet att andra uppskattar det man gör." - och kan "hjälpa andra att nå sina mål." "Att känna att man kan påverka saker i och med det man arbetar med."

Att göra ett bra jobb, göra nytta talar $19 \%$ av männen om. Några procent mer än kvinnorna. Det är helt enkelt viktigt "Att man arbetar." Det är betydelsefullt "Att man är nöjd med vad man gör och man kan vara stolt över sig själv." Man "gör skillnad och ser den skillnaden.” ”Att andra människor får det bättre (göra nytta) när jag gör detta, nu eller i framtiden." Man "gör nytta för sig själv och för samhället.” Viljan att vilja arbeta gör det meningsfullt; "viljan att vilja göra det:"

Det ska vara roligt, och man ska trivas i gemenskap med människor och medarbetare. Man ska gilla att träffa andra. Av männen har jag kategoriserat 28\% i denna kategori. Det meningsfulla är att "Du vistas i sociala sammanhang." "Man får träffa andra människor och man blir glad av alla människor man möter." "Mår du bra är ditt arbete meningsfullt." Du får umgås med "kompisar/kollegor. Stämningen mellan oss som arbetar." "Ha roligt, tjäna mycket, kunna försörja sin familj." "För mig är det sociala viktigt. På de flesta arbetsplatser interagerar man med andra människor. Pengar är också viktigt, men den sociala delen av jobbet kan vara lika lockande." "Man ska trivas och det ska vara möjligt att ständigt kunna utvecklas i sitt arbete. Man ska brinna för sitt arbete." "Samhörigheten som bör finnas på en arbetsplats och att jag får dra mitt strå till stacken." Det är viktigt "att man trivs och är nöjd samt att man kan bidra men något positivt till omgivningen."

Av männen är det $6 \%$ som på olika sätt påpekar att man utvecklas genom sitt arbete. "Man lär sig nya saker hela tiden. Man mognar i sitt sätt. Inkomsten - har stor betydelse 
på grund av att det som är meningsfullt med själva jobbet är inkomsten." "Man gör något och får en inkomst till ett bättre liv."

Det är också 6\% som tar upp själva meningsfullheten och skriver personligt om detta. "Ett arbete är aldrig meningsfullt. Det fyller enbart en mening i livet och det är att generera pengar. Hur man än kollar kan man inte få ut mer mening och betydelse från ett jobb.” Bland denna grupp talas också om att arbetet ska vara intressant, lärorikt och omväxlande. Arbetet ger dig "stora möjligheter" som en man skriver. Utöver inkomst och arbetskamrater så hade "det varit tråkigt att inte jobba alls."

En stor grupp män talar om betydelsen av pengar. Man ska ha bra betalt, vara självständig och som några tar upp - kunna försörja en familj. "Få en inkomst så man kan köpa ett boende o köpa mat till sin familj." "Cash - pengar och pengar." "Du klarar dig inte ekonomiskt utan ett jobb. Det ger dig pengar och i dagens samhälle är pengar allt. Ett jobb ger dig pengar för dina tjänster. Hur härligt är inte det?”

Bland männen tänker $46 \%$ tankar som att "Just nu är det bara tankar på pengar." Vilket är drygt tio procent mer än kvinnogruppen.

Många anser att arbetet ska ge tillbaka "socialt och pengar" och att det ska vara "kul och givande."

Det är dubbelt så många vet ej och blanka svar hos männen om vi jämför med kvinnorna, $6 \%$.

Kommentar: Trenden på denna fråga är om vi generaliserar och jämför svaren att kvinnorna i högre grad vill tjäna andra och solidariskt hjälpa till i arbetsprocessen samt prioriterar arbetsgemenskap med andra kollegor mer än männen som till större grad anser att det endast är lönen i pengar som är arbetsmödan värd. Gemenskap berörs av $58 \%$ kvinnor och $28 \%$ män. Pengar tas upp av 35\% kvinnor och $46 \%$ män. Några genomtänkta religiösa värderingar av arbetets meningsfullhet finns inte i materialet. Heller inga utvecklade tankar om politiskt motiverade attityder, arbetsetik och arbetsmoral. Bland annat, gissar jag, beroende på att sådana texter och sådan undervisning i ringa grad förekommer inom So-undervisningen.

\section{Sammanfattande reflektioner.}

En undersökning från 2005 (se not 15) på 550 gymnasieelever visade att kvinnorna var nästan dubbelt så positiva till arbete som pojkarna. På min fråga; Är det viktigt för Dig att ha ett arbete? - svarar de 299 gymnasieelever jag undersökt följande. Av de 123 männen svarar $63 \%$ ja och bland de 176 kvinnorna svarar $61 \%$ ja. Den positiva attityden till arbete är till och med något större i den manliga gruppen. Det mest anmärkningsvärda är kanske att det ändå är omkring 40\% som tycker det är meningsfullt med något förbehåll som exempelvis att man arbetar för pengarnas skull.

På frågan om ett arbete måste vara roligt så är det en större grupp kvinnor som anser så. Det är $73 \%$ kvinnor som tycker att ett arbete ska vara roligt, alltid eller ofta. Jämförande siffra hos männen är $51 \%$. 
Ungefär hälften bland både män och kvinnor tycker att ett arbete alltid och ofta kan förändra livet. Slås kategorierna alltid och ofta samman så blir resultatet $48 \%$ kvinnor och 46\% män. Återstående menar att det kan vara fallet ibland.

På det sätt som livet kan förändras visar det sig att pengars betydelse är viktigare för männen liksom i någon grad arbetskompisars livsförändrande betydelse. En förändringsfaktors betydelse som att flytta från hemorten eller till ett arbete syns mer medvetandegjord i kvinnogruppen.

När det gäller en lång utbildnings nödvändighet för ett drömjobb så tolkar jag det som om kvinnorna i högre utsträckning än männen tar det om det krävs för ett framtida arbete. Det är nästan hälften av den manliga gruppen som inte tycker att en lång utbildning är nödvändig. Svarsbilden på denna fråga är dock splittrad och svårtolkad.

Viljan att arbeta är ungefär lika stor i båda grupperna. Lägger man samman alltid och ofta så svarar 39\% kvinnor jakande och 35\% män. Det är emellertid fem gånger så många män procentuellt sett som aldrig skulle arbeta om de inte behövde det. Det går kanske att påstå att vissa män har en något latare attityd till arbete än kvinnor.

Trivseln på arbetet är viktigt bland både kvinnor och män $(69 \%$ kvinnor och 55\% män). Pengar är mer än dubbelt så viktigt för männen som för kvinnorna, relaterat till deras drömjobb (14\% kvinnor och 31\% män). Männen verkar också mer egoistiskt lagda i sina svar. Starka arbetsrelationer och arbetsgemenskap är viktigare för kvinnogruppen. Kvinnor har också större krav på att ett arbete ska vara roligt. Ibland i betydelsen att arbetet ska vara givande. Längtan efter pengar är genomgående starkare uttryckt i den manliga svarsgruppen.

Innan undersökningen hade jag förväntat mig större skillnader mellan grupperna i synen på pengar och på viljan att arbeta. Synen på pengars betydelse är genomgående inte lika starkt uttryckt som jag hade förväntat mig. Viljan att arbeta för sin egen skull och för andra är framsagt tydligare än jag trodde innan undersökningen. Arbetsviljan rent generellt är större än jag förväntat mig.

\section{Efterskrift}

Arbetsetik och arbetsmoral - Vem talar om detta idag? Ska vi döma av vad som kommer fram från de fyra berättelsernas innehåll så är det relativt ovanligt. Det är begrepp som får de flesta att aktivera sitt mentala försvar och bli på sin vakt. Nämn det för en politiker och de flesta kommer att flacka med blicken och bli osäkra på vilket svar de förväntas ge.

Varför är det så? Troligtvis är det en komplicerad svarsbild som växer fram. Begreppen signalerar vaksamhet och anses nog allmänt som otidsenliga och högtravande och föder fram tankar om institutionaliserad religion, krav och påtvingad samhällsnytta. Allt detta är inget som talar till de som är unga idag.

Det finns också en social sida av begreppen och deras användning. Traditionellt har det varit den övre och ekonomiskt starkare klassen som begärt arbetsmoral och striktare etiska ramar av sina underställda och anställda i industri och tjänsteföretag. Det är 
arbetstagarna som utkrävs visa arbetsmoral, sällan arbetsgivarna. I ett Vi och Dom perspektiv är det nog alltid "De andra" (arbetargruppen) som ska visa sig arbetsamma, ta sitt ansvar och hålla igen på orimliga lönekrav. Denna snedfördelning gör heller inte begreppen lättare att handskas med i privata och offentliga samtal. Begreppen föder misstänksamhet.

Att utifrån ett perspektiv grundat på utsagor i de stora världsreligionernas skrifter tala om arbete som människans "plikt” eller om arbete som en nödvändig "gudomlig” uppfostran av syndigt och ursprungligt lata människobarn är nog heller inte något didaktiskt förhållningssätt som är gångbart idag.

Begreppen arbetsetik och arbetsmoral relateras ofta automatiskt till tvång och otidsenlighet. Detta är svårt att ändra på bland annat därför att begreppen och deras innehåll sällan eller aldrig diskuteras eller debatteras. Detta gäller i massmedia såväl som i den svenska skolan eller inom aktuell dagspolitik. Begreppen undviks. De har blivit tabu. Då blir det också omöjligt att koppla begreppen till nutida samhällsdebatt. Arbetsetik och arbetsmoral blir omoderna relikter.

Främst unga människor, över hela Europa, blir alltmer utlämnade och utsatta på en flexibel och relativt dyster arbetsmarknad. Får de arbeten är de vanligtvis drabbade av osäkra arbetsförhållanden utanför den etablerade jobbsektorn. De får i bästa fall tillfälliga påhugg men sällan fasta arbeten. De måste ständigt vara mobila och beredda på uppbrott. De har ringa möjligheter att planera sina liv, avsätter ingenting till pension och har ingen anställningstrygghet och får heller aldrig någon yrkesidentitet eftersom de aldrig får in en fast fot i arbetslivet. Den här relativt stora gruppen kallar den engelska ekonomiprofessorn Guy Standing för "prekariatet" (Se hans bok The Precariat - The New Dangerous Class från 2011). De är ofta unga och välutbildade men har efter dyra studier skulder som bara växer. De har ett fåtal arbeten att söka efter sina avslutade studier och ibland inom sektorer där tjänsteutbudet av olika anledningar minskar drastiskt. Infångade i universitetsstudier med förespeglingar om en ljus framtid kastas de sedan ut i en arbetsmarknad som är om inte stendöd så i drömlös sömn. Detta kan på sikt resultera i att vi får en stor grupp välutbildade men arbetslösa, relativt unga men missnöjda människor fyllda i värsta fall med samhällsförakt, aggressivitet och hat. En het potatis att hantera för Europas många politiker. Inte minst därför är det viktigt att diskutera arbete och arbetets mening och varför vi ska arbete. Vad är ett arbete värt? Hur ska den ofrivilliga arbetslösheten hanteras i framtiden? Det kanske behövs, som somliga polemiskt tycks mena, en ekonomisk garanti, en medborgarlön som betalas ut om en person trots sin utbildning och arbetsvilja aldrig kommer in på arbetsmarknaden. En annan fråga som kräver sin reflektion är; Vilket är statens ansvar?

Vad kan skolan göra? Är det hela skol- och utbildningssystemet som behöver ses över? Kan samhället acceptera att många unga slutar skolan utan ett fullständigt gymnasiebetyg eller hoppar av skolan i förtid. Hur ska dessa redan utsatta grupper kunna komma in i arbetslivet eller antas till kompletterings- eller yrkesutbildning? 
Kommer det att finnas en arbetarklass i det framtida Europa? Kommer den kanske att förstärkas av en ökad invandring? Vad har denna arbetarklass i så fall för gemensamma frågor? Det manuella arbetet i Europa är redan något som alltmer utförs av andra, oftast av människor med utomeuropeiskt ursprung. Kanske är det därför som kroppsarbete eller så kallade okvalificerade arbeten värderas så lågt. Värderingen av det manuella arbetet behöver onekligen höjas. Även om utbudet av renodlat kroppsarbete i Europa minskar så kan man fråga sig; Vad är det för fel med att arbeta med kroppen? Tillhör kroppsarbete bara fritiden i form av gym och idrottsutövning? Också detta är relaterat till arbetets mening och värde. En stor del av dessa arbetstillfällen som kräver kroppsarbete dräneras också från Europa till fattigare länder. Det är inte bara så att det är "de andra” som utför arbetsuppgifterna utan de flyttas också någon annanstans utanför beställarens kontroll. I stora fabriker och sammansättningsindustrier gömda i fattiga utvecklingsländer sys kläder, mobiler sätts samman, leksaker tillverkas, frukt plockas, grönsaker konserveras och vi konsumerar som vanligt mest aningslöst. I dessa tillverkningsländer existerar ofta minimal arbetsrätt, svältlöner, barnarbete och vidriga arbetsförhållanden hör till vardagen och vi, vi bara konsumerar. Rapporter om ohyggliga arbetsplatser vi inte trodde fanns, kommer och går. Det stormar en stund i medierna och så blir det tyst igen - glömskan är snabb liksom nyhetsflödet. Det är lätt att bli uppgiven, cynisk och handlingsförlamad. Även i ett sådant perspektiv är det viktigt att diskutera arbete och arbetets mening och värde. Vad är ett arbete värt? Varåt är vi på väg? Finns alternativ? Hur blir framtiden och kan den påverkas?

I Sverige talas det om Arbetslinjen - de flesta partierna hakar på när tåget ska gå efter denna linje. Tåget är försenat som vanligt. Det är kallt, växlar fryser fast, och med värmen i kupéerna är det si och så. Låt mig få fortsätta allegorin som uttrycksform.

Vi befinner oss på stationen Arbetslivet. Tåget utrustas för avfärd. På en järnvägsvagn står det Sysselsättningspolitik och på en annan Ungdomsarbetslöshet. I kupén diskuteras förlängd skolplikt som ett sätt att möta problemen - eller blir det kanske ett sätt att dölja problemen? Ju längre tid i skola desto senare debut i statistiken över arbetslösa. Det kanske behövs två års plikt i eftergymnasial utbildning som nästa steg. En tredje vagn heter Jobbpolitik - där är rätt så tyst och så kallad idétorka verkar råda. En vagn heter Arbetsförmedling men kanske ska den vid nästa avgång byta namn till Kompetensförmedling. Samma riktning, samma räls, samma spårvidd - Vad ändras egentligen av ett namnbyte? Ja finns det inga jobb att förmedla längre så är det ju en adekvat ändring. Annars finns det ju som vi vet en mänsklig benägenhet att skifta namn på företeelser och institutioner som har misslyckats eller skaffat sig dåligt rykte - Är det fallet här?

En annan vagn är en som kallas Jobbpakt. I den sitter arbetsgivare, regering och fack i förhandlingar. Den vagnen växlas ständigt in på sidospår - ibland går den bakåt ibland framåt och inte sällan står den still. Det finns också specialutrustade vagnar. En heter Aktivitetsstöd och en heter Utvecklingsersättning. Dessa vagnar har ett förvirrande och vilset innehåll och ingen vet deras rätta destination. Men det är väl som Woody Guthrie 
sjunger i sin sång ”This train is bound for glory”. Så det är bara att hålla tummarna och eventuellt lita på högre makter.

Det står också Norge på en vagn som är fullastad med arbetssugna ungdomar som relativt nyligen gått ut gymnasiet och gärna ville jobba ett tag. De finner emellertid snart nog att några jobb inte finns i Sverige och arbetsförmedlingsvagnen med alla sina personliga jobbcoacher sätter dem i en egen vagn på spåret mot väst och så var ett problem borta eller i alla fall undangömt tills vidare. Att hitta ett arbete verkar vara ett tyngre arbete än att arbeta.

En elak allegori som kanske inte stämmer fullt ut men visar ändå tror jag på hur arbetsmarknadspolitiken kan upplevas när den betraktas lite från ovan av en som nalkas pensionen.

Min mening är att det är dags att återupptäcka begreppen arbetsetik och arbetsmoral och föra in dem i dagsdebatten såväl som i läromedelslitteraturen för grundskola och gymnasium. Att osynliggöra begreppens existens är fel väg att gå. Begreppen behövs om det ska kunna föras en fullvärdig debatt och diskussion om arbetets mening och värde. Det är oftast de mest laddade begreppen som tillför samhällsdebatten nytt bränsle.

Rätten till ett arbete när man vill och kan arbeta är en viktig grundregel för ett fungerande välfärdsland. De som står utanför arbetslivet blir som vi vet lätt alienerade från samhället vilket i sin tur är ett hot mot demokrati och solidaritet. Polariserade gruppers bristande förståelse för varandra kan lätt leda till social oro och vi får en situation som kan bli samhällsfarlig.

Det är alltså viktigt för ett lands ledning att erbjuda de förutsättningar som krävs för att så många som möjligt kommer i arbete och kan bidra till samhällets utveckling på ett kreativt och meningsfullt sätt. Den tjeckiske författaren Karel Čapek säger i sin bok "Ett år med min trädgård” (1934/1987) om att du vill arbeta

för att det roar dig

för att du kan det du gör

för att du har din utkomst av det

Detta är en bra sammanfattning av arbetets mening och värde oavsett om du arbetar i din egen trädgård eller i andras.

\section{Referenser}

Abrahamsson, Marianne. Grundbok Religion PULS. Stockholm 2006.

Alm, Lars-Göran. Religionskunskap för gymnasiet. Kurs A. Stockholm 1997/2009.

Almgren, Hans. Höjelid, Stefan. Nilsson, Erik. reflex. Samhällskunskap för gymnasie-

skolan. A-B-C- kurs. Malmö 1995.

Almgren, Hans. Wikén, Stefan. Almgren, Birgitta. Historia Kompakt. Malmö 1999.

Almgren, Hans. Löwgren, Arne. Bergström, Börje. Alla tiders historia. Maxi. Malmö 2003. 
Appelros, Erica. Hornborg, Anne-Christine. Röcklinsberg, Helena. Din tro eller min?

Religionskunskap för gymnasiet. Kurs B. Stockholm 2007.

Arendt, Hannah. Människans villkor. Vita activa. Göteborg 1998.

Armstrong, Karen. Myternas historia. Stockholm 2005.

Arlebrand, Håkan. Arvidsson, Bengt. Axelsson, Hans. Hermansson, Magnus. Tidman,

Nils-Åke. Relief A+B Religionskunskap. Malmö 1998.

Arlebrand, Håkan. Olofsson, Hans. Uppström, Rolf. Religion A. Stadiebok/Grundbok 1-3.

Malmö 2007.

Bainton, Roland, H. Luther. Mannen som blev en epok. Stockholm 1960.

Bauhn, Per. 'Mening, identitet och moral', Filosofisk Tidskrift 2/1998, 3-16, 1998.

Berg, Leif/Ericson, Gudrun. Religion och liv 8. Stockholm 1996.

Berg, Leif/Husén, Lennart. Religion och liv 7-9. Sol 2001. Stockholm 1997.

Berg, Leif/Ericson, Gudrun. Pedagogens pärm. Religion och liv 9. Stockholm 1998.

Berg, Leif. Religion och liv 8. Sol 3000. Lärarpraktika. Stockholm 2003.

Berg, Leif/Rundblom, Gunilla. Religion och liv 7. Sol 3000 Fokus. Stockholm 2005.

Berg, Leif/Rundblom, Gunilla. Religion och liv 8. Sol 3000 Fokus. Stockholm 2006.

Bhagavad-Gita. Vishet och yoga (övers. M. Gansten). Stockholm 2001.

Bischofberger, E/Fagerberg H. Människan inför livsfrågorna. Stockholm 1980.

Buber, Martin. Människans väg. Ludvika 1993.

Clark Hodges, Donald. 'Towards a Philosophy of Labor', The American Journal of Economics and Sociology Vol. 21, No. 4, Oct. 1962.

Dalai Lama. Etik för ett nytt millennium (övers. A. Galfvensjö). Malmö 2000.

Dahlqvist, Hans. 'Finns det liv efter lönearbetet? En idéhistorisk framställning om synen på arbetets värde’ i Samhällshistoria i Fokus. En festskrift till Lars Olsson om arbete, migration och kultur, s 16-31. (Red. Lars Berggren et al). Malmö 2010.

Den svenska Psalmboken. Antagen av 1986 års kyrkomöte.

Dex, Shirley. Women's attitudes towards work. Basingstoke 1988.

Drugge, Ulf. Krisbiografier. Utfattig och mindre fattiga förr. Malmö 2007.

Diehl, Anita/Wesslegård, Melker. Religion för högstadiet. Stockholm 1989.

Den poetiska Eddan (övers. Björn Collinder). Uddevalla 1964.

Snorres Edda (övers. Björn Collinder). Uddevalla 1970.

Englund, Liselotte. 'Arbetstidsförkortning - ett hot mot hälsan?', Tvärsnitt 2/05, s6f, Stockholm 2005.

Erlander, Lillemor. 'Arbete och social rättvisa'. I Kyrkans samhällsansvar. (red C-H Grenholm). Stockholm 1975.

Falkevall, Björn/Thor, Annika/Wärnegård, Ewa. Religionskunskap för grundskolans senare år. Stockholm 2001.

Frankfort, Henri. Ancient Egyptian Religion. New York 1961.

Gendrop, Paul. Mayafolket. Lund 1998.

Gerleman, Gillis/Johnson, Bo. Ur Gamla Testamentet. Kommentarer till valda texter. Lund 1972.

Goodwin, Barbara. Ethics at work. Issues in business ethics. Norwell 2000.

Grenholm, Carl-Henrik (red). Arbetets värde. Studiebok i kristen arbetsetik. Lund 1977. 
Grenholm, Carl-Henrik. Arbetets mening. En analys av sex teorier om arbetets syfte och värde. Uppsala 1988/1994

Groth, Bente. Judendomen. Stockholm 2002.

Gustafson, K.G. Jan. Den snubblande lyktbäraren. Kalmar 1998.

Habbe, Peter. Att se och tänka med ritual. Kontrakterande ritualer i de isländska släktsagorna. Lund 2005.

Hallgren, Roland. The Good Things in Life. Löberöd 1988/1991a.

Hallgren, Roland. 'Vestafrika: Yoruba'. I Skriftløse folks religioner (Red. Jørgen Podemann Sørensen). København 1988b.

Hammarén, Nils/Johansson, Thomas. Identitet-Vilka är du? Stockholm 2007.

Hamilton, Edith. Grekisk livssyn. Stockholm 1959.

Harjula, Raimo. The Ideal of the Good Life. As Crystallized by Tanzanian Meru Proverbs. (Studio orientala nr. 81) Helsinki 1997.

Hartman, Lars. (utgivare) En bok om nya testamentet. Lund 1973.

Harris, Marvin. Culture, people, nature. An introduction to general anthropology. New York 1975.

Hedengren, Uriel. Dilemma - om rätt och fel, etik och moral. Stockholm 2002

Hedin, Christer. Islam enligt Koranen. Furulund 1996.

Helldén, Arne. Arbete. Ur arbetets idéhistoria. Södertälje 1979.

Hermansson, Magnus/Tidman, Nils-Åke. Religionskunskap. SO-boken. Malmö 1995.

Hermerén, Harry. Religionskunskap för grundskolans högstadium. Lund 1970.

Hermerén, Harry/Lilja, Einar. Religion och tanke. Lund 1970.

Hildingson, Kaj/Hildingson, Lars. Levande Historia 8-9, Sol 3000. Stockholm 2003.

Hof, Hans, Hammarstedt, Jan. Nilsson, Clarence. Människan och livsåskådningarna.

Religionskunskap för gymnasiet och fackskolan. Stockholm 1969.

Hof, Hans/Hammarstedt, Jan. Människan och livsåskådningarna. Fördjupningstexter. Stockholm 1971.

Holm, Pelle. Ordspråk och talesätt. Stockholm 1973.

Husén, Lennart. Ståldal, Gunnar. Lundblad, Birgitta. Zetterholm, Tore. Religionskunskap. Lärobok i kristendomskunskap för grundskolan. Arskurs 9. Stockholm 1971.

Ingemark, Domenic/Gerding, Henrik/ Castoriano, Martine. Liv och död i Antikens Rom. Lund 2000.

Jacobsen, Knut A. Hinduismen. Historia, tradition, mångfald. Stockholm 2004.

Jegers, I/Lindgren, M. Morgondagens värderingar. Uppsala 1992.

Jönsson, Ludvig. Människan, mödan och arbetsglädjen. Stockholm 1974.

Jönsson, Rune/Liljefors-Persson, Bodil. 'Solidaritetens gränser - eller: Är ett leende värt mer än ett par tior?’ I Religion \& livsfrågor nr. 1, s 20, 2005.

Kapleau, Roshi Philip. Zens tre pelare. Smedjebacken 1995.

Karlgren, Bernard. Religion i Kina. Antiken. Stockholm 1964.

Khader, Naser. Familjeliv och levnadsmönster bland mellanösterns muslimer. Stockholm 1996.

King, Noel Q. African Cosmos. Belmont 1986.

Koranens Budskap (översättning Muhammed Knut Bernström). Stockholm 1998.

Koskinen, Lennart. Tro på framtiden. Kap V, Det goda arbetet. Stockholm 1994. 
Kragh, Ole. 7000 ordspråk och talesätt från hela världen. Arlöv 1981.

Kramer, Samuel Noah. Så levde sumererna. Stockholm 1958.

Körner, Göran. Lagheim, Lars. Lagheim, Anna. Puls. Samhällskunskap för grundskolans senare del. Stockholm 2002.

Landgren, G.A. Ordspråk, sanna språk. Stockholm 1889/1979.

Levi, Lennart. Stressen i mitt liv. Stockholm 2002.

Luther, Martin. D:r M. Luthers Lilla Katekes med kort utveckling. (Femtonde upplagan).

Långström, Sture. Nilsson, Erik. Swanelid, Göran. Samhällskunskap Kompakt. Malmö 1996.

de Montaigne, Michel. Om fåfänglighet och andra essayer. Stockholm 1962.

Nilsson, Lilian. Hinton, Per. Selander, Sven-Åke. Texter om livet och människan. Stockholm 1981.

Nylund, Bo. Wesslegård, Melker. Religion för högstadiet. Stockholm 1989.

Nylund, Bo. Wesslegård, Melker. Religion 1. Rondo. Västerås 1995.

Näsström, Britt-Mari. Fornskandinavisk religion. Lund 2001.

Näsström, Britt-Mari. Romersk religion. Lund 2005.

Olivestam, Carl-Eber. Thorsén, Håkan. Westermark, Ann. Livstro. Stockholm 1992.

Oremus. Svensk katolsk bönbok. Fjärde fullständigt omarbetade upplagan. Stockholm 1991.

Ovidius. Metamorfoser. Stockholm 1961.

Palmenfelt, Ulf. Ordspråk i tiden. Stockholm 1991.

Pihl, Herman Gottfrid/Roman, Anna Maria. Småskolans Kristendomsbok. Stockholm 1950.

Radler, Alexander. Kristendomens idéhistoria. Från medeltiden till vår tid. Lund 1995.

Ray, Benjamin. C. African Religions. Englewood Cliffs 1976.

Ringgren, Helmer/Ström, Åke V. Religionerna i historia och nutid. Stockholm 1974.

Ringgren, Helmer. Forntida religioner i Mellanöstern. Löberöd 1987.

Rodhe, B.C. Första läsåret. ABC - och läsebok. Göteborg 1891.

Rodhe, Sten. Sundström, Erland. Religionskunskap. Stockholm 1985.

Ryberg, Lars. Etik och livsfrågor. Stockholm 2002.

Sandberg, Robert. Karlsson, Per-Arne. Modin, Karl. Ohlander, Ann-Sofie. Epos historia.

För gymnasieskolan kurs A och B. Stockholm 2006.

Selander, Sven-Åke. Beltzén, Nils. Benktson, Bengt Erik. Bogren, Yngve. Pettersson, Olof. Livsfrågor. Lund 1979.

Seneca. Om livets korthet (övers. Johan Bergman). Stockholm 1949.

Seneca. Letters from a stoic (Penguin Classics). Harmondsworth 1969.

Siurala, Lasse. Youth attitudes towards work. Helsinki 1982.

Stabell Bilgrov Jens AA. 20.000 proverbs. Köpenhamn 1985.

Stenberg, Leif. (et al). Världsreligioner i vardagen. Globalt och i Sverige. Stockholm 2005.

Stolpe, Herman. Arabiska ordspråk och visdomsord. Stockholm 1965.

Stolpe, Herman. Kinesiska ordspråk och visdomsord. Stockholm 1969a.

Stolpe, Herman. Ryska ordspråk. Stockholm 1969.

Stolpe, Herman. Isländska ordspråk och skaldeord. Stockholm 1974.

Stolpe Herman. Afrikanska ordspråk. Stockholm 1980.

Ström, Fredrik. Svenska ordspråk. Stockholm 1981. 
Svenskt Bibliskt Uppslagsverk (SBU). Andra upplagan, Band I. Stockholm 1962 och Band II Stockholm 1963.

Söderblom, Nathan. Humor och melankoli och andra Lutherstudier. Stockholm 1919.

Tacitus. Germania. (tolkning av Alf Önnerfors). Stockholm 1961.

Tengström, Jacob. Läseöfning för mina barn. Åbo 1798.

Theorell, Töres. 'Att inte få leva djurliv fast man är gjord för det - ny kunskap om långvariga stressreaktioner i det nya arbetslivet'. I Tvärsnitt 2/05 s 8ff. Stockholm 2005.

Thulin, Birgitta/Alm, Sten. Religion A o B 2000. Malmö 2001.

Tidman, Nils-Åke/Hermansson, Magnus. Religionskunskap. Kompakt. Malmö 1999.

Valmin, Natan. Arbete och slaveri i antiken. Stockholm 1937.

Vergilius, Publius Maro. Georgica- sånger om lantbruket (översättning Tönnes Kleberg). Stockholm 1989

Volf, Miroslaw. Work in the spirit. Toward a Theology of Work. New York 1991.

Wagner, Ulf. (red). Tro i tid och rum. Malmö 1996.

Wallensteen, Ivar/Brusewitz, Gunnar. Världens bästa ordspråk. Västerås 1991.

Wergel, Karin. Hildingson, Kaj. Hildingson, Lars. Samhälle i dag 7-9. Elevbok. Stockholm 2003.

Westerberg, Boel/Holgersson, Ulla-Karin/Samuelsson, Wiwi. Religionskunskap. Möte med livsfrågorna. Temaboken Puls. Stockholm 1996.

Westerberg, Boel/Samuelsson, Wiwi. Religionskunskap. Möte med livsfrågorna. Puls 7-9 Förklaringar och fakta. Stockholm 1997.

Wikander, Ola (översättning). Enuma elish. Det babyloniska skapelseeposet. Stockholm 2005.

Yutang, Lin. Konsten att njuta av livet. Stockholm 1999. 